\title{
The Intergenerational Education Spillovers of Pension Reform in
}

\section{China}

\author{
Cheng Yuan*, Chengjian $\mathrm{Li}^{* *}$ and Lauren A. Johnston*** \\ * Cheng Yuan (corresponding author): School of Economics, Peking University, Beijing \\ 100871, China, Tel: 8610-6275-4871, 86-15611180743, Email: yc@pku.edu.cn. \\ ** Chengjian Li: Development Research Center of the State Council, Beijing 100010, China; \\ Peking University, Beijing 100871, China, Tel: 86-15300176625, Email: 1cj@drc.gov.cn. \\ *** Lauren A. Johnston: Melbourne Institute of Applied Economic and Social Research, \\ University of Melbourne, Australia, 3010. Tel: 61-3-83445032; Email: \\ lauren.johnston@unimelb.edu.au.
}

Thanks to the editor and two anonymous referees for helpful comments and suggestions; participants of the $22^{\text {nd }}$ (2016) Panel Data Conference and a Melbourne University seminar, and Jie Ma for important feedback; Hui Chen for research assistance; and a Dyason Fellowship for financial support.

\begin{abstract}
:
Economic theory establishes that pension privatisation weakens the link between old and young, and so reduces the incentive to invest in public education in an economy with lower return rate of capital than that of labor. However, empirical studies of the link are few. We take contemporary pension reforms in a number of Chinese provinces as offering natural experiment conditions. Using a difference-in-difference framework and 282 municipal districts panel data over years 1998-2009, we test the pension-education theoretical link. Our results confirm that pension privatisation is adversely associated with local public spending on education in China. Private pension subsidies, moreover, exaggerate this effect. Our study supports the theoretical assertion and selective empirical findings of a negative intergenerational effect of pension privatisation.
\end{abstract}

Keywords: Pension System, Fully Funding of the Individual Accounts, Public Education Spending, Local Public Finance

JEL Classification: H52 H55 I22 


\title{
The Intergenerational Education Spillovers of Pension Reform in
}

\section{China}

\begin{abstract}
:
Economic theory establishes that pension privatisation weakens the link between old and young, and so reduces the incentive to invest in public education in an economy with lower return rate of capital than that of labor. However, empirical studies of the link are few. We take contemporary pension reforms in a number of Chinese provinces as offering natural experiment conditions. Using a difference-in-difference framework and 282 municipal districts panel data over years 1998-2009, we test the pension-education theoretical link. Our results confirm that pension privatisation is adversely associated with local public spending on education in China. Private pension subsidies, moreover, exaggerate this effect. Our study supports the theoretical assertion and selective empirical findings of a negative intergenerational effect of pension privatisation.
\end{abstract}

Keywords: Pension System, Fully Funding of the Individual Accounts, Public Education Spending, Local Public Finance

JEL Classification: H52 H55 I22

\section{Introduction}

Population aging is becoming the norm across industrialised high-income economies and increasingly in middle-income countries also, including in China. Understanding the direct and indirect economic consequences, and ensuring the costs are sustainable over generations is a topic that is steadily receiving greater attention in the economics literature (e.g., Orszag and Stiglitz, 2001; Bloom, Canning and Fink, 2010; Mason, Lee and Jiang, 2016). In this paper, we build on the contested literature on the links between population aging and education expenditure (e.g., Harris Evans and Schwab, 2001; Gradstein and Kaganovic, 2004; Kurban, Gallagher and Persky, 2015). Specifically, we examine the theoretical link between pension system structure and public education expenditure and test this through a difference-indifference analysis of recent pension reforms in China.

Inter-generational interdependence underpins the willingness of the working generation to invest in the education of the future generation, in the absence of altruism. Promise of an oldage pension incentivizes the working-age population to invest not just in the pensions of today's old, but also in the public education of the young. The latter relates to the fact that enhanced 
future human capital and labor productivity serve current worker self-interest through increased future retirement benefits. This intergenerational welfare lock-in mechanism of the incometransfer system is moreover found explicitly to better incentivize the current working-age population to invest in public education in pay-as-you-go (PAYG) schemes compared to private contribution-based pension schemes (Pogue and Sgontz, 1977). Since the mid-1980s however, in many countries pension reforms have shift away from PAYG and toward partial-funded private contribution-based systems.

There is a rich empirical literature on the link between aging populations on public education spending. Poterba (1998) provides a comprehensive survey of seminal earlier works. In general, the conclusions of the existing empirical literature are, however, unfortunately mixed. For examples, Poterba (1997), Brunner and Balsdon (2004), and Arvate and Zoghbi (2010) identify a negative relationship between the share of local elderly population and public support for local school finance. In contrast, Goldin and Katz (1997), Kurban, Gallagher and Persky (2015), and Ohtake and Sano (2010) find support for a positive relationship. As Poterba (1998) points out, there are many factors affecting the links between population aging and public education expenditure, and the links may change over time and vary from area to area. Undoubtedly, the pension system is one of the most important mechanisms under which the link works, but it is largely either neglected or not controlled for in the previous empirical research. In this paper, we will fill this gap by investigation of how pension system reform affects the intergenerational linkage between the old and the young by taking pilot pension reforms in China as a natural experiment.

Until the 1990s China had a universal PAYG pension system. "Fear of aging" (Johnston et al, 2016) with respect to the unknown economic consequences of decades of state-led family planning restrictions empowered a dramatic experimentation with partially funded systems, from 2001. That year, thirteen provinces began experimenting with a system of individual pension accounts, and establishing a step away from the intergenerational PAYG system (see Table 1 for province list). Under these experiments, in contrast, employed persons would directly contribute to their own private pension fund. In line with theoretical elaboration by Brunner (1993), in China in practice this experimentation has generated its own set of challenges. Examples include that contributions to private pension accounts have been diverted to cover deficits in PAYG pooled social accounts that remain responsible for funding current pensioners. In many provinces and municipalities that challenge has left the experimental individual pensions accounts as notional concepts only.

Pension reforms impact the individual's lifetime budget constraint, and in turn are consequential for decision-making around working, saving, retirement and education. Among these, pension system influence on current worker willingness to invest in public education is the main channel via which the pension system impacts education investment and thus the 
accumulation of human capital. This makes it meaningful to empirically study the effect of the pension reform on public education expenditures. Moreover, in the case of China, the country is not only home to the world's largest stock of pensioners, and also a uniquely structured pension reform process. Moreover, $\mathrm{Mu}$ and $\mathrm{Du}$ (2015) have shown that promise of a pension in old age increases intra-household education spending on the next generation. China thus presents an interesting case for empirical exploration of the theoretical links between pension type and public education investment. Additionally, that pension reforms in China have in recent years taken place exclusively in a set of thirteen provinces provides a treatment group within a national provincial-level natural experiment. In this paper, we use a difference-indifference matching framework to study differences between them.

In the theoretical literature, endogenous growth theory literature especially, has considered the question of the relationship between lifetime savings and education investment. Typically such studies apply the Overlapping Generation (OLG) model to explore the impact of pension reform on public education expenditure. An early such study, Pogue and Sgontz (1977), introduces several new variables including altruism, heterogeneity in education, and political process. Buiter and Kletzer (1995) consider public choice theory in a three-period OLG model, finding that intergenerational redistribution policies that discourage physical capital formation may encourage human capital formation. Kaganovich and Zilcha (1999) construct an OLG model with a PAYG system and altruistically motivated transfers from parents to children. They find that where government allocates funds with the aim of maximizing the growth rate, it might not be optimal to maintain a PAYG pension system. But where parents' preferences endogenize strong forward concern for their own welfare in retirement with a significant degree of altruism towards their children, then a PAYG system does enhance growth and welfare. Kaganovich and Meier (2012) and Kemnitz (2000) both show that PAYG retirement systems support more funding to public education in a voting model. Becker and Barro (1988) and Boldrin and Montes $(2005,2009)$ use an over-lapping generations framework to also point out that intergenerational transfer agreements are efficient where they induce equality between certain implicit rates of return. ${ }^{1}$

Pension systems can also offset deficiencies in public education expenditures using nonmarket institutions. Rangel (2003) builds an OLG model without altruism that identified that where there is a lack of incentives of the current generation to invest in the education of the next generation, an additional institution is required to accommodate the absence of incentives. This type an institution is endogenous to the PAYG pension system in the combined provision of education by the working-aged generation with pensions paid in retirement directly from

\footnotetext{
${ }^{1}$ Sinn (2004) proves that the PAYGO system induces a moral hazard effect in terms of reducing the individual incentives for an investment in human capital; and Cigno (2010) suggests similar conclusion. However, their findings may hold for the case of private education, not for public education.
} 
contributions of the ensuing working-age generation, solving the problem that education investment is otherwise inefficiently low. Iturbe-Ormaetxe and Valera (2004) construct an OLG model with endogenous labor supply and in which individuals live for three periods. They identify that diversion of some funds from the PAYG scheme to a full-funded system reduces societal support for funding the education system. The reason is that such reforms weaken the link between future pension provisions and the quality of current education.

In sum, the literature finds that reforming a pension system from a PAYG system to a partially funded system is not conducive to sustained public education spending. Most of this literature, however, has been of a theoretical design, or qualitative. Choi (2006) argues that in South Korea, home to one of the world's most rapidly ageing populations, intra-generational redistribution must be at the core of public pension reform experimentation. In contrast, there have been very few empirical tests of the prediction. One reason for the lack of empirical studies is that pension reform is usually accompanied by transition costs that make it hard to determine whether the decline in public education investment is caused by the weakening of the intergenerational connection. Other causes, for example, could include a local fiscal constraint induced by the parallel transition costs.

In this paper, we explore the relationship between changes to the pension system and education expenditures in China from an intergenerational contract perspective. We specifically use the case study provided by China's recent individual pension account experimentation, to explore the influence of pension system structure on local public education spending. We develop a three-period OLG model without a role for altruism, and in which the local government's objective is to maximize local social welfare. The local government does this by continuously choosing between consumption, savings and education investment over three periods. This theoretical outline of the relationship between pension system type and education expenditure identifies that pension privatisation is detrimental to local public education expenditures.

We adopt a difference-in-difference framework to study whether pilot pension reforms that were exclusively implemented in selected Chinese provinces empirically support our theoretical conclusions. Our panel data is from the municipal district level and encompasses the period 1998-2009. Making appropriate adjustments to our methodology to account for the fact that pension reforms are provincial level, our empirical results support our theoretical assumptions: private pension contribution schemes are adversely associated with the willingness of successive working-age generations to collectively invest in the education of the next generation. A private pension subsidy from the central government that was also selectively implemented is found to exaggerate this effect. These results support earlier research identifying a story of intergenerational contract weakening around pension privatisation. 
The rest of this paper is organized as follows. Section 2 develops a three-period OLG model without altruism, and studies the theoretical link between pension reform and public education spending. Section 3 reviews the evolution of China's recent pension reforms, and discusses these in relation to the theoretical model of Section 2. Section 4 sets out a differencein-difference (DID) model with heterogeneity and describes the data and variables used for the related empirical analysis. Section 5 describes the data and variables. Section 6 reports and interprets the results of the DID analysis. Section 7 summarizes and concludes the paper with policy and research recommendations.

\section{The Model}

We assume a standard three-period OLG, in which a representative individual lives for three periods as follows: receives a public education while accumulating human capital in the first period $(t)$; works, raises children and saves in the second period; retires and consumes savings in the third period. In the period $t$, the number of young individuals who live through to their second period is $L_{t}$, and the growth rate of population is $n$. In the following period, $t+1$, the number of young individuals is thus $L_{t+1}=L_{t}(1+n)$. Although Cigno (1992) has demonstrated that a generous pension system is negatively associated with fertility, since we explore the link between social security and public education investment, in our model fertility is exogenous and we concentrate on education investment.

\subsection{Components}

\subsubsection{Firms}

In the first period, $t$, the human capital of young individuals is $H_{t}$, total available capital is $K_{t}$, and total output, $Y_{t}$, takes Cobb-Douglas form: $Y_{t}=K_{t}^{\alpha} H_{t}^{1-\alpha}$. With $y_{t}=Y_{t} / H_{t}$ as the ratio of output to human capital, we have:

$$
y_{t}=k_{t}^{\alpha}, f^{\prime}\left(k_{t}\right)>0, f^{\prime \prime}\left(k_{t}\right)<0 \text {. }
$$

where $k_{t}=K_{t} / H_{t}$ and is the ratio of capital to human capital. It is assumed that capital fully depreciates after one period of production. Factor markets are perfectly competitive, and the rate of return to each factor is the marginal product of the factor, i.e.,

$$
r_{t}=\alpha k_{t}^{\alpha-1}-1
$$




$$
w_{t}=(1-\alpha) k_{t}^{\alpha}
$$

where $r_{t}$ represents the interest rate in period $t$, and $w_{t}$ is the wage rate.

\subsubsection{Education}

Local government taxes labor income to invest in education. The tax rate for education is $\tau_{t}$, and the associated funds from which are exhausted in investing in educating the next generation. Assume that the proportion of total wages used to pay for the education of dependent youth in education is $e_{t}\left(e_{t}=\tau_{t}\right)$, and that the production function of human capital, $H$, follows Cobb-Douglas form:

$$
H_{t+1}=E_{t}^{\beta} H_{t}^{1-\beta}=\left(e_{t} w_{t} H_{t}\right)^{\beta} H_{t}^{1-\beta}=\left(e_{t} w_{t}\right)^{\beta} H_{t},
$$

where $E_{t}$ represents the total investment on youth education in period $t$. In Equation (3) private education investment is not considered. In the context of public education, Cigno et al. (2003) and Cigno (2010) have shown the public education spending is controlled directly by the government, meaning that the principal-agent problem induces working parents to behave differently in private and public education spending. In this paper, however, we focus on public education spending. Were we however, to consider private education investment, the crowdingout effect between public and private education spending (Yuan and Zhang, 2015) would otherwise strengthen the influence of pension system reform on public education spending, and not reverse it.

The human capital per young individual, $h_{t}$, and $H_{t}=h_{t} L_{t}$. Equation (3) can thus be written as:

$$
(1+n) h_{t+1}=\left(e_{t} w_{t}\right)^{\beta} h_{t}
$$

\subsubsection{Individuals}

For simplicity, we assume any consumption in childhood is incorporated into the parents' consumption. Individuals of working age are required to invest in the government-nominated pension scheme. That pension system has two elements: the social pooling account that works as a pay-as-you-go (PAYG) system and individual accounts that are intended to follow a singular agent through the lifespan. The rate of contribution into the social pooling account is 
$\lambda_{t}^{p}$, and the rate of contribution into individual accounts is $\lambda_{t}^{m}$. Both $\lambda_{t}^{p}$ and $\lambda_{t}^{m}$ are decided by the central government. A representative working-aged individual needs to pay a tax toward the public education of dependent youth at a tax rate of $\tau_{t}$ and also saves proportion $s_{t}$ of wage income. In period $t$, an old agent is entitled to receive pension $p_{t}+m_{t}$, where $p_{t}$ reflects funds sourced from the social pooling account and $m_{t}$ are funds sourced from an individual account.

The representative agent's optimization problem is:

$$
\operatorname{Max} u\left(c_{2, t}, c_{3, t+1}\right)=\ln c_{2, t}+\rho \ln c_{3, t+1}
$$

s.t.

$$
\begin{aligned}
& c_{2, t}=\left(1-\lambda_{t}^{p}-\lambda_{t}^{m}-s_{t}-\tau_{t}\right) w_{t} h_{t} \\
& c_{3, t+1}=\left(1+r_{t+1}\right) s_{t} w_{t} h_{t}+p_{t+1}+m_{t+1}
\end{aligned}
$$

where $c_{2, t}$ is consumption in period $t$ of a working-age agent born in period $t-1 ; c_{3, t+1}$ is consumption in period $t+1$ of a dependent aged agent born in period $t-1 ; \rho<1$ represents the pure rate of time preference.

Solving the FOC of the utility maximization problem yields:

$$
\begin{gathered}
c_{2, t}=\frac{1}{1+\rho}\left[\left(1-\lambda_{t}^{p}-\lambda_{t}^{m}-\tau_{t}\right) w_{t} h_{t}+\frac{1}{1+r_{t+1}}\left(p_{t+1}+m_{t+1}\right)\right], \\
s_{t}=\frac{\rho}{1+\rho}\left(1-\lambda_{t}^{p}-\lambda_{t}^{m}-\tau_{t}\right)-\frac{1}{1+\rho} \frac{1}{1+r_{t+1}} \frac{\left(p_{t+1}+m_{t+1}\right)}{w_{t} h_{t}} .
\end{gathered}
$$

\subsubsection{Government}

In the current period $t$ of pension reform, the central government reduces $\lambda_{t}^{p}$, the contribution rate into the social pooling account; incentivizes $\lambda_{t}^{m}$, the working-age agent contribution rate into individual accounts; and keeps the total contribution level unchanged, 
$d \lambda_{t}^{m}+d \lambda_{t}^{p}=0$. To ensure the benefits of aged dependents ${ }^{2}$, local government exhausts the contributions of working-age agents, including contributions to individual accounts, to fund the pension of aged dependents. This reduces the system to an effective PAYG system, and thus leaves individual accounts, which are intended to follow a singular agent through the lifespan, as notional and empty. The central government in turn gives some matching-funding required subsidies to local governments to support the funding of otherwise emptied individual accounts, and also to support the implementation of the broader pension reform program. Working-age agents contribute $\lambda_{t}^{m}$ of wage into individual accounts but are not able to access the equivalent of their contributions when they retire. This relates to the fact that their individual account contributions are effectively used as if a PAYG system was in place in that they in fact fund the pensions of current aged dependents. Instead, working-age individual account investors in retirement only receive a share of the individual pension funds they had expected, and which is comprised of two components: subsidies from the central government and a fund provided by the local government ${ }^{3}$. It is noteworthy also that the fund supplied by the local government is actually transferred from the social pooling account. Subsidies from the central government are equivalent to $\theta \lambda_{t}^{m} w_{t} h_{t} L_{t}$, where $0 \leq \theta \leq 1$ and which is related to the contribution of the individual account from the working-age agent. Under the requirement to match central contributions, the local government utilizes a share of the social pooling account to fund the individual accounts, which itself does not increase the funding scale of social security. A balanced equilibrium of the pension system in turn requires that:

$$
\left(m_{t+1}+p_{t+1}\right) L_{t}=\lambda_{t+1}^{p} w_{t+1} h_{t+1} L_{t+1}+\theta \lambda_{t}^{m} w_{t} h_{t} L_{t}\left(1+r_{t+1}\right)
$$

where $\theta \lambda_{t}^{m} w_{t} h_{t} L_{t}\left(1+r_{t+1}\right)$ is sourced from central government, and $\lambda_{t+1}^{p} w_{t+1} h_{t+1} L_{t+1}$ is the funding share from the social pooling account. Substituting $L_{t+1}=L_{t}(1+n)$ and equation (4) into equation (7) gives:

$$
m_{t+1}+p_{t+1}=\lambda_{t+1}^{p} w_{t+1}\left(e_{t} w_{t}\right)^{\beta} h_{t}+\theta \lambda_{t}^{m} w_{t} h_{t}\left(1+r_{t+1}\right) .
$$

Local governments cannot change the wage range and interest rate, which are set monolithically nationally. A local government has only the power to choose the optimal level of public education spending to maximize local resident welfare. The government has no altruism. The government's exclusive objective is to maximize the social welfare of the

\footnotetext{
${ }^{2}$ Since the aged dependent agents have no decision-making power on education investment on the third and youngest generation, their status of benefits or loss has no impact on the working generation's decision on education spending. Thus, for simplicity, we assume the local government ensures retiree benefits in the pension reform.

${ }_{3}^{3}$ The local government is required to match central subsidy by funding some part of the individual account using local fund.
} 
working-age generation. The local government's optimization problem thus is:

$$
\operatorname{Max} \quad G=\ln c_{2, t}+\rho \ln c_{3, t+1}
$$

s.t.

$$
\begin{aligned}
& c_{2, t}=\frac{1}{1+\rho}\left[\left(1-\lambda_{t}^{p}-\lambda_{t}^{m}-\tau_{t}\right) w_{t} h_{t}+\frac{1}{1+r_{t+1}}\left(p_{t+1}+m_{t+1}\right)\right] \\
& c_{3, t}=\left(1+r_{t+1}\right) \rho c_{2, t} \\
& m_{t+1}+p_{t+1}=\lambda_{t+1}^{p} w_{t+1}\left(e_{t} w_{t}\right)^{\beta} h_{t}+\theta \lambda_{t}^{m} w_{t} h_{t}\left(1+r_{t+1}\right) \\
& e_{t} w_{t} h_{t}=\tau_{t} w_{t} h_{t}
\end{aligned}
$$

where $e_{t} w_{t} h_{t}=\tau_{t} w_{t} h_{t}$ means that the local government exhausts education taxes collected on public education spending.

\subsubsection{Capital markets}

Since we assume that the capital fully depreciates after one period's production, the available capital next period is sourced entirely from savings in the current period, namely $K_{t+1}=\left(s_{t}+\lambda_{t}^{m}\right) w_{t} H_{t}$. Thus, we obtain:

$$
k_{t+1}=\frac{K_{t+1}}{H_{t+1}}=\left(s_{t}+\lambda_{t}^{m}\right) w_{t}^{1-\beta} e_{t}^{-\beta}
$$

\subsubsection{Equilibrium}

Solving the FOC of the social welfare maximization problem yields ${ }^{4}$ :

$$
e_{t}^{1-\beta}=\frac{w_{t+1}}{1+r_{t+1}} \beta \lambda_{t+1}^{p} w_{t}^{\beta-1}
$$

Substituting $\frac{w_{t+1}}{1+r_{t=1}}=\frac{1-\alpha}{\alpha} k_{t+1}$ and equation (9) into equation (10) gives:

$$
e_{t}=\frac{1-\alpha}{\alpha} \beta \lambda_{t+1}^{p}\left(s_{t}+\lambda_{t}^{m}\right)
$$

Substituting equation (8) and (10) into equation (6) gives:

\footnotetext{
${ }^{4}$ See the solving process in Appendix A.
} 


$$
s_{t}+\lambda_{t}^{m}=\frac{\rho}{1+\rho}\left(1-\lambda_{t}^{p}-e_{t}\right)-\frac{1}{1+\rho} \frac{e_{t}}{\beta}+\frac{1-\theta}{1+\rho} \lambda_{t}^{m} .
$$

Substituting equation (12) into equation (11) gives:

$$
\begin{array}{r}
e_{t}=\frac{1-\alpha}{\alpha} \beta \lambda_{t+1}^{p}\left[\frac{\rho}{1+\rho}\left(1-\lambda_{t}^{p}-e_{t}\right)-\frac{1}{1+\rho} \frac{e_{t}}{\beta}+\frac{1-\theta}{1+\rho} \lambda_{t}^{m}\right] \\
\quad \text { or } e_{t}=\frac{(1-\alpha) \beta \lambda_{t+1}^{p}\left[\rho\left(1-\lambda_{t}^{p}\right)+(1-\theta) \lambda_{t}^{m}\right]}{\alpha(1+\rho)+(1-\alpha)(1+\rho \beta) \lambda_{t+1}^{p}} .
\end{array}
$$

Substituting equation (13) into equation (12) gives:

$$
s_{t}+\lambda_{t}^{m}=\frac{\alpha\left[\rho\left(1-\lambda_{t}^{p}\right)+(1-\theta) \lambda_{t}^{m}\right]}{\alpha(1+\rho)+(1-\alpha)(1+\rho \beta) \lambda_{t+1}^{p}} .
$$

\subsection{Pension reform}

Recall that the central government reduces the contribution rate into the social pooling account, $\lambda_{t}^{p}$, enhances the contribution rate into individual accounts $\lambda_{t}^{m}$, and keeps $d \lambda_{t}^{m}+d \lambda_{t}^{p}=0$. In the successive period, the contribution rate into the social pooling account $\lambda_{t+1}^{p}$ is unchanged, namely $\lambda_{t+1}^{p}=\lambda_{t}^{p}$. We now analyze the effect of pension reform on education expenditure and the total saving rate.

If the central government fully subsidises the transition cost of pension reform (the case of $\theta=1)$ then we can specifically study the effect of the pension system itself since there is no impact on the budget constraint. When $\theta=1$, substituting $\lambda_{t+1}^{p}=\lambda_{t}^{p}$ into equations (13) and (14), and differentiating them with $\lambda_{t}^{m}$ gives:

$$
\begin{gathered}
\frac{d e_{t}}{d \lambda_{t}^{m}}=\frac{(1-\alpha) \rho \beta\left[(1-\alpha)(1+\rho \beta) \lambda_{t}^{p} \lambda_{t}^{p}-\left(1-2 \lambda_{t}^{p}\right) \alpha(1+\rho)\right]}{\left[\alpha(1+\rho)+(1-\alpha)(1+\rho \beta) \lambda_{t}^{p}\right]^{2}}, \\
\frac{d\left(s_{t}+\lambda_{t}^{m}\right)}{d \lambda_{t}^{m}}=\frac{\alpha \rho \alpha(1+\rho)+\alpha \rho(1-\alpha)(1+\rho \beta)}{\left[\alpha(1+\rho)+(1-\alpha)(1+\rho \beta) \lambda_{t}^{p}\right]^{2}} .
\end{gathered}
$$

Equation (15) means that the effect of pension reform on education expenditure is 
uncertain. Variables that determine it include the share of labor income in total output $(1-\alpha)$, the efficiency of human capital production $\beta$, and the contribution rate of social pooling account $\lambda_{t}^{p}$, etc. If $(1-\alpha)(1+\rho \beta) \lambda_{t}^{p} \lambda_{t}^{p}<\left(1-2 \lambda_{t}^{p}\right) \alpha(1+\rho)$, public education spending will fall as individual accounts are expanded. Intuitively, under the condition that the rate of return on individual accounts (equal to the interest rate) is less than that of the social pooling account (equal to the growth rate of total wages), an increase in the proportion of individual accounts will lower the total rate of return on education investment, which in turn reduces the enthusiasm to invest in education. As demonstrated by Acemoglu (2009), when capital accumulation is higher than the optimal level ${ }^{5}$, the interest rate will be lower than the growth rate of total labor income, which will instigate a shift in preference away from a PAYG and toward a fully funded collective system.

In the particular case of China, the saving rate is relatively high, and it is plausible to expect that the interest rate is lower than the growth rate of total labor income. From 1998 to 2009 , the average growth rate of total labor income is $12.7 \%$; the interest rate is always less than $5 \%$ and its average level is about 3\%; namely the interest rate is far below the growth rate of total labor income. It is thus expected that by enhancing the contribution rate of individual accounts, the return rate on education investment falls, and accordingly the working generation reduces its education investments. If $(1-\alpha)(1+\rho \beta) \lambda_{t}^{p} \lambda_{t}^{p}>\left(1-2 \lambda_{t}^{p}\right) \alpha(1+\rho)$, public education spending will increase proportionately with the enhanced the share of individual accounts; and this case is consistent with the conclusion in Kaganovich and Zilcha (2012), which used a similar model to the model being used herein.

Equation (16) infers that $\frac{d\left(s_{t}+\lambda_{t}^{m}\right)}{d \lambda_{t}^{m}}>0$, or namely that the total saving rate will increase as the contribution rate to the individual account increases. Intuitively, reducing the contribution rate going into the social pooling account means the pension from next generation will decrease, suggesting that the working-age generation should increase private savings in order to retain the same quality of life in their later years of retirement.

The central government formulated pension system policy reforms. First, it decided the values of $\lambda_{t}^{m}, \lambda_{t}^{p}$ and $\lambda_{t+1}^{p}$. To subsidise pension reform transition costs and promote the

\footnotetext{
5 Acemoglu (2009) interprets the difference between the neoclassical growth model and the OLG economy. In the neoclassical model, there exists a representative household whose utility maximization decision ensures that the economy is never in the dynamic inefficiency region, and the transversality condition of the representative household rules out that interest rate is less than the growth rate of human capital. However, this is no longer the case in the OLG economy.
} 
reform agenda, the central government provided some subsidies, $\theta \lambda_{t}^{m} w_{t} h_{t} L_{t}$, the size of which relates to individual account revenue. We take $\lambda_{t}^{m}, \lambda_{t}^{p}$ and $\lambda_{t+1}^{p}$ as given, and focus solely on the effect of subsidy rate $\theta$ on education spending and the total saving rate. Differentiating equations (13) and (14) with respect to $\theta$ gives:

$$
\begin{gathered}
\frac{d e_{t}}{d \theta}=\frac{-(1-\alpha) \beta \lambda_{t+1}^{p} \lambda_{t}^{m}}{\alpha(1+\rho)+(1-\alpha)(1+\rho \beta) \lambda_{t+1}^{p}}<0 \\
\frac{d\left(s_{t}+\lambda_{t}^{m}\right)}{d \theta}=\frac{-\alpha \lambda_{t}^{m}}{\alpha(1+\rho)+(1-\alpha)(1+\rho \beta) \lambda_{t+1}^{p}}<0
\end{gathered}
$$

Equation (17) infers a definitive result: the ratio of education expenditure to wage income will decrease as the subsidy rate from the central government increases. Intuitively, a subsidy increase increases the earnings of individual accounts in the next period, and consequentially weakens intergenerational ties such that governments invest less in the productivity of future workers via current public education. Equation (18) infers that the total saving rate will decrease as the subsidy rate from the central government increases. In addition, a subsidy increase increases pensions in the next period, in turn incentivizing a fall in savings in the current period.

In this Section, we have set up an OLG model including social security system, and shown that enhancing the contribution rate into individual accounts will reduce the public education spending under some conditions. In fast-growing countries with education sectors characterized by a dominant public model for education services, as in the case of China, this is a plausible reflection of the economy. Moreover, these effects are compounded by subsidies from central government for individual accounts weakening intergenerational ties further, and in turn further reducing the incentive to invest in public education.

\section{Overview of recent pension reform in China}

China had a PAYG system that was exclusively based on social pooling pension accounts, until 1997. Following the State Council promulgation "Decision on Establishing a Unified Basic Old Age Pension Insurance System for Enterprise Staff and Workers" (The State Council 1997, Document No. 26) private accounts were selectively introduced. The Decision's specific mandate was that employers should contribute $20 \%$ over and above an employee's wage to a pension fund, of which $17 \%$ should go to a pooled account, and $3 \%$ to an individual account. Initially, employees were required to contribute $4 \%$ of employee wage, increasing by one percent every two years, to 8 percent by 2005 , and all of which was directed to the individual account. In parallel 11 percent of payroll was also to be put into individual pension accounts, 
comprised of $8 \%$ contributions from employees and a 3\% contribution from employers. These changes mark the shift in China's pension system to being officially comprised of two elements: the social pooling account based on a PAYG system and a parallel structure of individual pension accounts. Imposition of these changes, however, varied across provinces and time. Thus, these changes also marked the introduction of heterogeneity to the structure of China's pension system.

In any complete or partial transition from a PAYG to a private pension system there must be a means of funding the pension entitlements of current retirees and also of current workers who having invested exclusively in the pooled system over a significant share of their working life. In China's case, in transition local governments used current PAYG contributions to finance both mandated individual account contributions and also to fund current pension payments that would otherwise have been paid from the social pool (which was newly relatively depleted because of the re-direction of some pension contributions to private accounts). Since many local governments were drawing upon individual account funds to pay current social pool pension obligations (see Chen and Turner, 2014; Zhu, 2002), the actual contribution rate into many individual accounts was effectively $0 \%$, instead of the mandated $8 \%$. This suggests that in fact a PAYG effectively remained in place alongside accumulating future unfunded private pension obligations. One estimate suggested that by 1994 China's related implicit pension debt was Rmb1917.6 billion (World Bank, 1996).

It was these circumstances that prompted pension reforms, led by the northeast province of Liaoning in 2001. The principle aim of the reforms was to meaningfully fund individual accounts on a sustainable basis. Reforms intended to achieve this were designed as a matching funds incentive system between central and local authorities. Under these reforms since 2001 actual individual pension account contributions in Liaoning province have received matching central subsides at a ratio of three to one. Over the first four years of the reform experimentation, from 2001 to 2004, the program realized pension subsidies for Liaoning province to the annual value of Rmb7.28, 9.23, 10.4, and 11 billion respectively. Local contributions together with agreed matching central contributions cumulatively reached $5 \%$ of employee wages - still below the then mandated nominal individual account contribution rate of $8 \%$ of the employees' wages, and an improvement on the emptiness of individual accounts prior to the matching fund reform experimentation.

Table 1 summarizes the introduction of recent pension pilot reforms in China. In 2004, two further provinces in China's northeast, Jilin and Heilongjiang, joined Liaoning province in embarking upon a process of pension reform. In 2006, the provincial-level authorities of Tianjin, Shanghai, Shanxi, Shandong, Henan, Hubei, Hunan and Xinjiang entered into the reform process also. In the case of later joining provinces, however, central reform subsidies were not the consistent equivalent of those received by inaugural reformist province Liaoning. Some 
provinces in fact received no central subsidies at all. For example, relatively economically developed provinces of Zhejiang and Jiangsu, which after joining the reform process in 2007 received no central subsidies. No additional provinces have joined the reform process since 2008.

Table 1 Pilot Provinces, Starting Year and Subsidies Access

\begin{tabular}{ccccc}
\hline \hline \multirow{2}{*}{ Pilot provinces } & \multicolumn{2}{c}{ Beginning time } & Subsidies from the \\
central finance
\end{tabular}

Provinces receiving public subsides toward pension reform experimentation (Table 1) received substantial cash advances to support funding of individual account pension payments. Inaugural pension reformist province Liaoning received Rmb6.35 billion in 2010 alone, equivalent to some 10 per cent of individual funds accumulated that year. In Japan, a country ahead of China in both economic development level and population ageing, it has been identified that inter-generational inequality is exaggerated by failure to consider the implications of social security spending across generations and in light of the interdependence of fiscal balances with interest rates (Tokuoka, 2012). By 2014, China's Minister of Finance went public with his view that the program of funding individual accounts was not sustainable. Soon thereafter, the privatisation pension reform agenda was terminated. A nominal account system was implemented as before therein.

The changes to China's pension system therein elaborated can be summarized in the language of our model as follows: the effective contribution rate to individual accounts, $\lambda_{t}^{m}$, is very low. The contribution rate to the social pooling account, $\lambda_{t}^{p}$, is higher than the nominal 
level. After selective regional pilot reform of individual accounts, and in consideration of subsidies from central government, the contribution rate to those individual accounts, $\lambda_{t}^{m}$, satisfied $\lambda_{t}^{m}>\lambda_{t-1}^{m}$. That is, positive net contributions were made into individual accounts in each contribution time period (while central subsidies were being received). In addition, the contribution rate of the social pooling account, $\lambda_{t}^{p}$, satisfied $\lambda_{t}^{p}<\lambda_{t-1}^{p}$. In other words, for provinces taking part in the reform process funds from individual accounts could no longer be diverted to paying for current pensioners, a result of which was that the funds available in provincial social pooling accounts fell.

Referring to our earlier theoretical outlay, our analysis will demonstrate how pension privatisation like that recently experimented with in selected Chinese provinces (Table 1) can also induce unintended effects. In our case, we study the effect of the fall in the incentive to contribute to public education. We also find that central subsidies intended to reduce unsustainable pension imbalances served also to aggravate the weakening of the link between generations, realized via a more marked impairment in the propensity to invest in public education between generations.

\section{The empirical model}

The basic empirical model is specified as follows:

$$
e d u_{i t}=\alpha+\beta \cdot y_{t}+\gamma \cdot P R_{i t}+z_{i t}^{\prime} \delta+c_{i}+\varepsilon_{i t}
$$

and where the dependent variable, $e d u_{i t}$ measures local public education spending, $\alpha$ represents a vertical intercept that is fixed across time and region, and $y_{t}$ is a set of year dummy variables controlling for common time trends in local public education expenditure across different regions. With $z_{i t}$ we control for a set of time-varying urban economic and demographic characteristics, including local (provincial) GDP per capita, the local fiscal situation and local demographic structure. Collectively the latter affect the local public education spending level and also are closely related to the criterion used by the central government in drawing up the provincial pension reform pilot list.

To manage omitted variable risks, we control for potential confounding factors in Equation (19) by including city fixed effects $c_{i}$, and year fixed effects $\beta \cdot y_{t}$, where $y_{t}$ represents a set of year dummy variables and $c_{i}$ captures city characteristics that are constant such as geographic and cultural features that may influence both the current local public education spending level and the central government's choice of pilot province. $\beta \cdot y_{t}$ captures common time trends, 
especially where related to annual nationwide education and pension policy variables that may affect both education spending and pension reform that are not otherwise captured. $\varepsilon_{i t}$ is an idiosyncratic error term that changes over time and place.

The dummy variable $P R_{i t}$ in equation (19) designates whether city $i$ carried out the pilot program of "Fully-funded Individual Accounts" or not in year $t$. If the city commenced "Pilot Reform" or "Fully Funded Individual Accounts" then $P R_{i t}$ equals 1; otherwise $P R_{i t}$ equals 0. The coefficient $\gamma$ can be interpreted as the causal effect of pension reform on local public education spending where the policy variable of $P R_{i t}$ is correctly specified as exogenous. That is, and as explained is the case studied herein, pilot pension reforms are an exogenous policy shock and variation of $P R_{i t}$ can be regarded as uncorrelated to the unobservable factors in $\varepsilon_{i t}$ that affect the local government's decision on education investment given the inclusion of the controls outlined. Estimation of $\gamma$ in equation (19) using two-way fixed effects estimation methods and a DID structure (Abadie, 2005; Donald and Lang, 2007). This allows us to capture the average real difference of public education expenditure between the pilot and non-pilot groups with similar characteristics following the implementation of the pilot program of funding individual accounts. This difference is calculated by taking the non-pilot cities as the control group.

As elaborated in Section 3, the central government offered large subsidies to some pilot provinces to support funding of pooled account pension obligations as well as the transition costs, and thus in effect to support the full funding of individual accounts. Relatively well-off pilot provinces that were later to join the reform process did not however, receive the same treatment from central government in that they did not receive subsidies at all. To capture this difference we construct an interaction term comprised of a subsidy dummy and pension reform dummy. This indicates whether a prefecture-level city in the pilot provinces was supported by the central subsidy scheme or not, and is equal to one where a city was part of the reform process and also received subsidies. Introduction of the interaction term $s u b s i d y_{i t} \cdot P R_{i t}$, divides the cities sample into 3 groups: non-pilot, pilot without central government subsidies, and pilot with central government subsidies. This allows us to observe the total effect of "Full funding of individual accounts" on education expenditure in place of simply dividing each city into treatment and control groups as in Equation (19). Accordingly, the DID model with heterogeneous effects is specified as follows:

$$
e d u_{i t}=\alpha+\beta \cdot y_{t}+\left(\operatorname{subsidy}_{i t} \cdot P R_{i t}\right) \cdot \gamma_{g}^{\prime}+z_{i t}^{\prime} \delta+c_{i}+\varepsilon_{i t}
$$

and where subsidy denotes whether city $i$ is part of the central government's pension reform subsidy scheme, and $\gamma_{g}$ is a vector of the DID effects of pension reform on public education 
expenditure for different policy groups.

\section{Data and Variables}

\subsection{Data}

China began a pilot program of funding individual accounts within the old-age pension system in 2001. The most recent wave of pilot reforms was carried out in 2006 and 2007. To study the effect of these reforms on public education expenditure, we exploit relatively stable annual data available since 1998 with respect to the education system. The record keeping, compliance monitoring, benefit calculation and disbursement of pooled social pension funds are administrated mainly at the prefecture level. From these records, we extracted a panel data set across 282 prefecture municipal districts within 27 provinces and provincial-level municipalities in China over years 1998-2009, excluding direct-controlled municipalities. The key variables at municipal level within the dataset can be classified into four groups: (1) economic development related variables such as regional consumer price index (CPI), regional Gross Domestic Product (GDP), GDP per capita, gross value added by sectors and industry share of GDP; (2) demographic structure related variables including total population, nonagricultural population, permanent resident population, urban population, and school-age share of population; (3) local government financial condition variables including local general budgetary revenue and expenditure, and local social security subsidy spending; (4) education related variables such as number of students in primary and middle school, number of full-time teachers, and local government expenditure for operating expenses of education in general budgetary expenditure. This data comes from several sources, including the Municipal Public Finance Statistics Yearbook published by the Ministry of Finance, China City Statistical Yearbook, China Urban Living and Price Yearbook, and the China County Statistical Yearbook.

Changes to the data over our sample period made it necessary to selectively augment the data. For example, in 2007 a few adjustments were made to revenue and expenditure classifications in China. Specifically, the category "educational operating expenses" from the Municipal Public Finance Statistics Yearbook changed into "public educational expenses". This new category absorbed "educational operating expenses", alongside infrastructure spending and administration fees by educational institutions as well as other education expenditures. To maintain data consistency we adjusted educational expenses from 2008 as follows:

Edu Operating Expenses after $2007=$ Edu Expenses $\_2007 *[1-($ Admin Expenses + Expenditure on Infrastructure by Edu Units/General Expenditure by Local Govt)=2006]

A similar case applies to the Bureau of Statistics decision from 2007 not to itemize 
individual items comprising the aggregated sum "social security and employment expenditure". Prior to 2007 this amount was listed under three distinct categories: "pensions and social welfare relief", "outlays for retirees from government administration" and "social security subsidies". We calculate the size of "social security subsidies" after 2007 for each city by a similar formula to educational operating expenses calculation. It is noted that the data for "social security subsidies" is accessible only at prefecture level, which includes municipal districts and county-level cities and counties under the administration of a prefecture city.

\subsection{Variables and descriptive statistics}

We construct the dependent variable "public education expenditure intensity" as the share of local GDP per capita comprised of local public education spending per student in primary and middle schools. This variable captures the proportion of the local representative individuals' income invested in the public education of one student. Since population growth is exogenous, the variable "public education expenditure intensity" is a proportion of $e_{t}$ as per our theoretical model (Section 2). This variable also inherently and objectively reflects the relative size of public education investment in different periods and also the scale of the relative incentive to allocate public resources to basic education. This measurement of local government level public education spending also has good comparability across time and across regions.

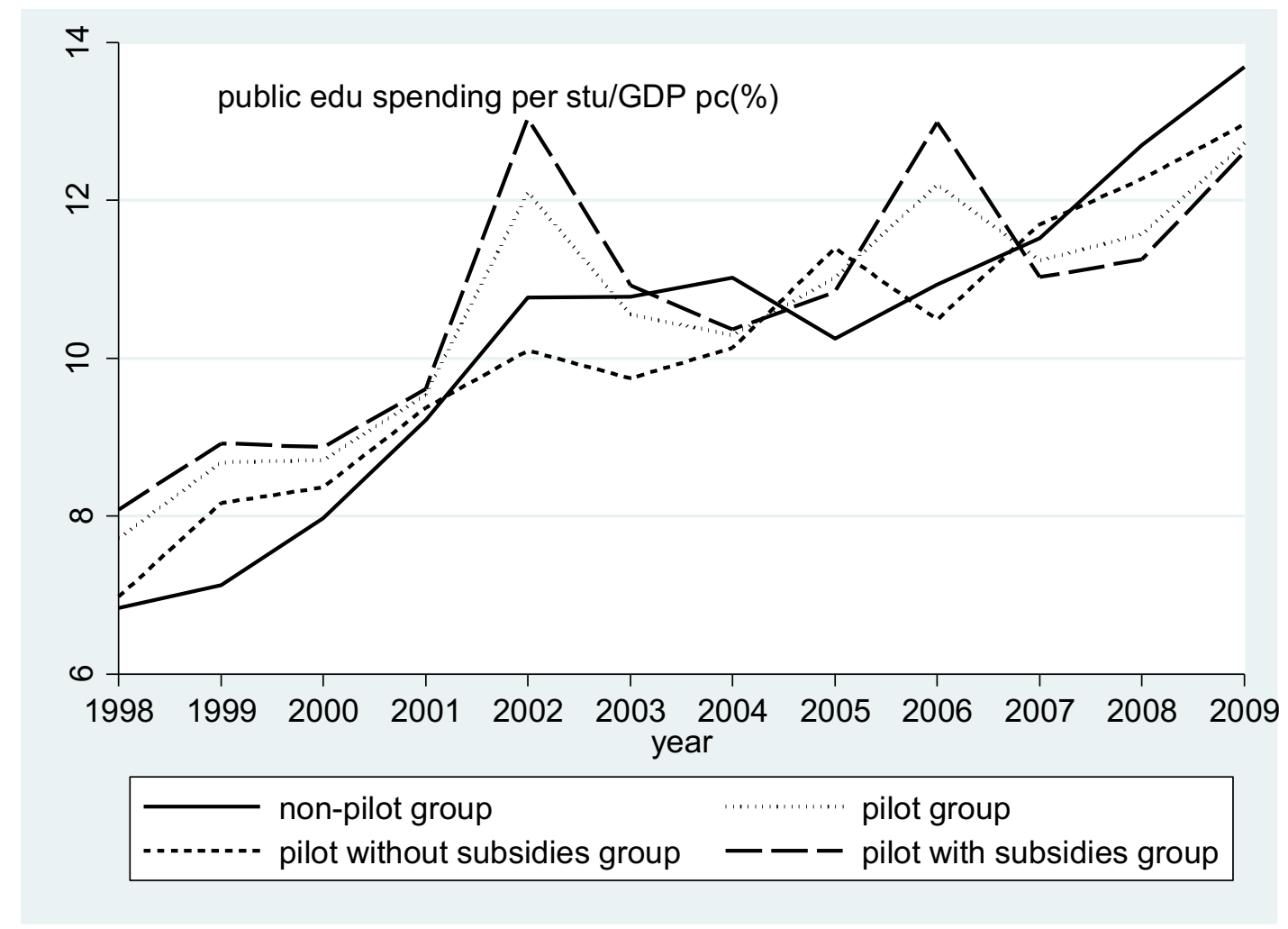

Figure 1 Public Education Expenditure Intensity for Different Groups 
Figure 1 illustrates that the intensity of public education spending for regions outside of the reform process (the non-pilot group), and for each of three differently grouped reform subject groups - pilot group (all regions undertaking pension reforms); the pilot without subsidies group and the pilot with subsidies group - broadly follows an increasing trend over the sample period. Importantly however, for non-pilot regions where no subsidies were offered toward funding individual accounts, public education spending intensity was noticeably lower than in the pilot regions - at first. After 2007, however, the education spending of the non-pilot regions surpassed the pilot regions. Further, the intensity of education investment in the pilot provinces whose pension reforms were supported by the central government subsidies seems higher than those without subsidies throughout the sample period before 2007. Fluctuation in the subsidized group is evidently sharper than within the unsubsidized group. In the context of pension policy reforms, fluctuation around the year 2006 especially is worth further examination.

In 200610 provinces in China entered a pilot pension reform program. Among these ten six provinces received no central government subsidies toward that reform process. Strikingly, the unsubsidized group has increased education spending since 2006 while the subsidized group reduced education expenditures. But since each pilot province had different schedules and timings of pension reform, the treatment effects cannot be directly observed from descriptive outlays such as Figure 1. To isolate the impact of pension reform, it is necessary to ensure necessary controls around factors that could independently influence local government decisions on education spending and central government decisions on the selection of pilot provinces.

Table 2 displays the descriptive statistics for the intensity of public education spending and other major explanatory variables used in our empirical analysis. The difference between the unsubsidized and subsidized pilot groups provides useful information. For example, that the unsubsidized pilot cities enjoy a much higher level of public education spending per student than the subsidized group but that this reflects a lower spending intensity in those provinces. The lower intensity of the former group is probably due to their having twice the average GDP per capita than the latter. The unsubsidized units also enjoy more favourable financial circumstances, including more plentiful fiscal revenue and a higher fiscal self-sufficiency rate. Local social security spending at the city level in the unsubsidized pilot cities is much lower than in the subsidized counterparts, whether measured in absolute level or in share ratio to GDP. One explanation for the latter might be the better employment conditions in urban areas of those provinces. For example, average registered urban unemployment rate in unsubsidized cities is $3.04 \%$, which is $1.3 \%$ lower than in the subsidized cities. The former rate also is subject to less variation than the latter.

Table 2 Mean of Major Variables for Different Groups 


\begin{tabular}{|c|c|c|c|c|}
\hline Variable & $\begin{array}{l}\text { Non-pilot } \\
\text { group }\end{array}$ & Pilot group & $\begin{array}{l}\text { Unsubsidized } \\
\text { pilot group }\end{array}$ & $\begin{array}{l}\text { Subsidized } \\
\text { pilot group }\end{array}$ \\
\hline Public education spending per student (RMB) & $\begin{array}{r}1563.49 \\
(1225.12) \\
\end{array}$ & $\begin{array}{c}1730.73 \\
(1522.44) \\
\end{array}$ & $\begin{array}{r}2249.87 \\
(1715.09)\end{array}$ & $\begin{array}{c}1516.09 \\
(1380.06)\end{array}$ \\
\hline $\begin{array}{l}\text { Share of Public education spending per } \\
\text { student/GDP pc (\%) }\end{array}$ & $\begin{array}{c}18.67 \\
(25.86)\end{array}$ & $\begin{array}{c}13.50 \\
(13.47)\end{array}$ & $\begin{array}{l}10.87 \\
(6.16)\end{array}$ & $\begin{array}{c}14.58 \\
(15.39)\end{array}$ \\
\hline GDP pc, RMB, in constant $1997 \mathrm{RMB}$ & $\begin{array}{c}11023.78 \\
(10892.51)\end{array}$ & $\begin{array}{c}14561.58 \\
(12156.66)\end{array}$ & $\begin{array}{c}21262.57 \\
(14579.44)\end{array}$ & $\begin{array}{l}11949.42 \\
(9916.45)\end{array}$ \\
\hline Population $(10,000$ people $)$ & $\begin{array}{c}325.33 \\
(229.13)\end{array}$ & $\begin{array}{c}403.01 \\
(241.46)\end{array}$ & $\begin{array}{c}509.52 \\
(223.85)\end{array}$ & $\begin{array}{c}361.38 \\
(235.32)\end{array}$ \\
\hline Share of value added in primary sector $(\%)$ & $\begin{array}{c}22.22 \\
(12.87)\end{array}$ & $\begin{array}{c}18.28 \\
(11.32)\end{array}$ & $\begin{array}{l}13.06 \\
(8.76)\end{array}$ & $\begin{array}{c}20.33 \\
(11.55)\end{array}$ \\
\hline Share of value added in secondary sector (\%) & $\begin{array}{l}36.67 \\
(8.93)\end{array}$ & $\begin{array}{l}35.13 \\
(7.99)\end{array}$ & $\begin{array}{l}34.31 \\
(6.16)\end{array}$ & $\begin{array}{l}35.45 \\
(8.58)\end{array}$ \\
\hline Share of value added in tertiary sector $(\%)$ & $\begin{array}{c}41.40 \\
(14.58)\end{array}$ & $\begin{array}{l}46.59 \\
(13.19)\end{array}$ & $\begin{array}{l}52.63 \\
(8.39)\end{array}$ & $\begin{array}{c}44.22 \\
(13.95)\end{array}$ \\
\hline Local general bdgt revenue per capita (RMB) & $\begin{array}{c}674.12 \\
(952.44)\end{array}$ & $\begin{array}{c}824.73 \\
(1025.52)\end{array}$ & $\begin{array}{c}1301.35 \\
(1358.97)\end{array}$ & $\begin{array}{c}638.17 \\
(786.05)\end{array}$ \\
\hline $\begin{array}{l}\text { Proportion of local general budgetary } \\
\text { revenue/GDP (\%) }\end{array}$ & $\begin{array}{c}5.58 \\
(3.76)\end{array}$ & $\begin{array}{c}4.95 \\
(1.86)\end{array}$ & $\begin{array}{c}5.34 \\
(1.90)\end{array}$ & $\begin{array}{r}4.80 \\
(1.82)\end{array}$ \\
\hline Local general bdgt expenditure (RMB) & $\begin{array}{c}1514.50 \\
(1487.87)\end{array}$ & $\begin{array}{c}1415.24 \\
(1225.07)\end{array}$ & $\begin{array}{c}1640.19 \\
(1421.00)\end{array}$ & $\begin{array}{c}1327.38 \\
(1127.92)\end{array}$ \\
\hline $\begin{array}{l}\text { Local social security subsidies per capita at } \\
\text { city level (RMB) }\end{array}$ & $\begin{array}{c}57.13 \\
(65.51)\end{array}$ & $\begin{array}{c}83.93 \\
(107.14)\end{array}$ & $\begin{array}{r}48.50 \\
(53.51)\end{array}$ & $\begin{array}{c}98.49 \\
(119.57)\end{array}$ \\
\hline $\begin{array}{l}\text { Local social security subsidies/local general } \\
\text { bdgt expenditure (city level, } \% \text { ) }\end{array}$ & $\begin{array}{c}3.89 \\
(2.93)\end{array}$ & $\begin{array}{c}5.69 \\
(5.06)\end{array}$ & $\begin{array}{c}2.68 \\
(2.00)\end{array}$ & $\begin{array}{c}6.93 \\
(5.41)\end{array}$ \\
\hline $\begin{array}{l}\text { Local social security subsidies/GDP (city } \\
\text { level, } \% \text { ) }\end{array}$ & $\begin{array}{r}0.64 \\
(0.73) \\
\end{array}$ & $\begin{array}{c}0.74 \\
(0.93)\end{array}$ & $\begin{array}{c}0.22 \\
(0.18)\end{array}$ & $\begin{array}{c}0.95 \\
(1.02)\end{array}$ \\
\hline Local fiscal self-sufficiency rate $(\%)$ & $\begin{array}{c}44.65 \\
(23.44)\end{array}$ & $\begin{array}{c}54.91 \\
(22.53)\end{array}$ & $\begin{array}{c}73.98 \\
(16.42)\end{array}$ & $\begin{array}{c}47.47 \\
(20.09)\end{array}$ \\
\hline Share of non-agricultural population (\%) & $\begin{array}{c}27.53 \\
(17.06)\end{array}$ & $\begin{array}{c}34.35 \\
(16.86)\end{array}$ & $\begin{array}{c}32.95 \\
(13.13)\end{array}$ & $\begin{array}{c}34.90 \\
(18.08)\end{array}$ \\
\hline Share of school age population $(\%)$ & $\begin{array}{l}16.13 \\
(6.56)\end{array}$ & $\begin{array}{l}14.46 \\
(3.25)\end{array}$ & $\begin{array}{l}13.52 \\
(2.54)\end{array}$ & $\begin{array}{l}14.83 \\
(3.42)\end{array}$ \\
\hline $\begin{array}{l}\text { Full-time teachers per } 100 \text { students in primary } \\
\text { and middle schools }\end{array}$ & $\begin{array}{c}5.33 \\
(1.77)\end{array}$ & $\begin{array}{c}5.94 \\
(1.39)\end{array}$ & $\begin{array}{c}5.73 \\
(0.94)\end{array}$ & $\begin{array}{c}6.03 \\
(1.53)\end{array}$ \\
\hline Registered urban unemployment rate (\%) & $\begin{array}{c}3.92 \\
(3.26)\end{array}$ & $\begin{array}{c}3.99 \\
(2.71)\end{array}$ & $\begin{array}{c}3.04 \\
(1.08)\end{array}$ & $\begin{array}{c}4.36 \\
(3.04)\end{array}$ \\
\hline City & 153 & 130 & 41 & 89 \\
\hline Observations & 2220 & 1752 & 492 & 1260 \\
\hline
\end{tabular}

Note: Numbers in parentheses are the standard deviations. 


\section{Estimation Results}

In our regression model the dependent variable is the intensity of public education spending, measured by the share of GDP per capita comprised by public education spending per student. Since this intensity is measured in percentage, the control variables are all constructed in percentage form to maintain scale comparability with the dependent variable. A sufficient condition for identification of a treatment effect, in this case as attached to pilot pension reform, is that selection to enter the treatment group does not depend on individualtransitory shocks under a two-way fixed effect panel data model. Where this requirement holds, then estimation of $\lambda$ from equation (19) and (20) is a DID estimator if the identification condition is satisfied.

\subsection{Overall effect of pilot pension reform}

Table 3 reports the regression results of the effects of pilot individual account subsidization on public education spending intensity. We vary the control variables in models (1)-(6), with all specifications consistently controlling for city and year fixed effects. To account for potential cross-sectional correlation in the estimation of panel models, we use Driscoll-Kraay standard errors for the regression analysis. ${ }^{6}$ The results under the 6 different specifications produce a relatively consistent estimated coefficient attached to pilot reforms.

Table 3 Regression results for public education spending on pilot pension reform

\begin{tabular}{|c|c|c|c|c|c|c|}
\hline \multicolumn{7}{|c|}{ Dependent variable: public education spending per student/GDP per capita (\%) } \\
\hline & (1) & (2) & (3) & (4) & (5) & (6) \\
\hline $\begin{array}{l}\text { Pilot reform of funding } \\
\text { individual accounts }\end{array}$ & $\begin{array}{l}-0.112 \\
(0.293)\end{array}$ & $\begin{array}{l}-0.136 \\
(0.290)\end{array}$ & $\begin{array}{l}-0.625 * \\
(0.331)\end{array}$ & $\begin{array}{l}-0.764 \% \\
(0.366)\end{array}$ & $\begin{array}{l}-0.781 * \\
(0.376)\end{array}$ & $\begin{array}{l}-0.650 * \\
(0.301)\end{array}$ \\
\hline $\begin{array}{l}\text { Share of value added in } \\
\text { primary sector }(\%)\end{array}$ & $\begin{array}{c}0.083 \\
(0.061)\end{array}$ & $\begin{array}{l}0.085 \\
(0.061)\end{array}$ & $\begin{array}{l}0.052 \\
(0.049)\end{array}$ & $\begin{array}{l}0.054 \\
(0.055)\end{array}$ & $\begin{array}{c}0.054 \\
(0.055)\end{array}$ & $\begin{array}{r}0.037 \\
(0.061)\end{array}$ \\
\hline $\begin{array}{l}\text { Share of value added in } \\
\text { tertiary sector }(\%)\end{array}$ & $\begin{array}{l}0.049 * \\
(0.015)\end{array}$ & $\begin{array}{l}0.048 * \\
(0.016)\end{array}$ & $\begin{array}{l}0.029 * \\
(0.016)\end{array}$ & $\begin{array}{l}0.029^{*} \\
(0.016)\end{array}$ & $\begin{array}{l}0.029 * \\
(0.015)\end{array}$ & $\begin{array}{r}0.018 \\
(0.018)\end{array}$ \\
\hline $\begin{array}{l}\text { Full-time teachers per } 100 \\
\text { students in primary and } \\
\text { middle schools }\end{array}$ & $\begin{array}{l}0.765^{*} \\
(0.318)\end{array}$ & $\begin{array}{l}0.771 * \\
(0.321)\end{array}$ & $\begin{array}{l}0.645^{*} \\
(0.276)\end{array}$ & $\begin{array}{l}0.649 * \\
(0.279)\end{array}$ & $\begin{array}{l}0.648^{*} \\
(0.279)\end{array}$ & $\begin{array}{l}0.562 * \\
(0.261)\end{array}$ \\
\hline $\begin{array}{l}\text { Share of school age } \\
\text { population }(\%)\end{array}$ & $\begin{array}{l}-0.258^{*} \\
(0.087)\end{array}$ & $\begin{array}{l}-0.258 * \\
(0.087)\end{array}$ & $\begin{array}{l}-0.279 * \\
(0.094)\end{array}$ & $\begin{array}{l}-0.279 * \\
(0.095)\end{array}$ & $\begin{array}{l}-0.280^{*} \\
(0.096)\end{array}$ & $\begin{array}{l}-0.340^{*} \\
(0.114)\end{array}$ \\
\hline $\begin{array}{l}\text { Registered urban } \\
\text { unemploy. rate (\%) }\end{array}$ & & $\begin{array}{l}0.035 \\
(0.033)\end{array}$ & $\begin{array}{l}0.025 \\
(0.023)\end{array}$ & $\begin{array}{l}0.023 \\
(0.022)\end{array}$ & $\begin{array}{l}0.023 \\
(0.022)\end{array}$ & $\begin{array}{l}0.042 * \\
(0.022)\end{array}$ \\
\hline
\end{tabular}

\footnotetext{
6 See Hoechle (2007).
} 


\begin{tabular}{|c|c|c|c|c|c|c|}
\hline $\begin{array}{l}\text { Local general bdgt } \\
\text { expenditure/GDP }(\%)\end{array}$ & & & $\begin{array}{c}0.471 * * * \\
(0.054)\end{array}$ & $\begin{array}{c}0.472 * * * \\
(0.054)\end{array}$ & $\begin{array}{c}0.473 * * * \\
(0.055)\end{array}$ & \\
\hline $\begin{array}{l}\text { Share of non-agricultural } \\
\text { population }(\%)\end{array}$ & & & & $\begin{array}{l}-0.004 \\
(0.008)\end{array}$ & $\begin{array}{l}-0.004 \\
(0.008)\end{array}$ & $\begin{array}{c}0.004 \\
(0.009)\end{array}$ \\
\hline $\begin{array}{l}\text { Local fiscal self- } \\
\text { sufficiency rate }(\%)\end{array}$ & & & & & $\begin{array}{c}0.006 \\
(0.005)\end{array}$ & $\begin{array}{r}-0.095^{* *} \\
(0.022)\end{array}$ \\
\hline $\begin{array}{l}\text { Local general bdgt } \\
\text { revenue/GDP (\%) }\end{array}$ & & & & & & $\begin{array}{l}1.034 * * \\
(0.273)\end{array}$ \\
\hline Observations & 3,203 & 3,202 & 3,202 & 3,161 & 3,160 & 3,160 \\
\hline Cities (number) & 282 & 282 & 282 & 282 & 282 & 282 \\
\hline
\end{tabular}

Notes: Driscoll-Kraay standard errors clustered in brackets; all columns are estimated with a two-way fixed effects model.

* Significant at $10 \%, * *$ Significant at $5 \%, * * *$ Significant at $1 \%$.

First, we find that the higher the shares of value added GDP share attributed to the primary and tertiary sectors the higher public education spending intensity. This result infers that local governments increasing spending on basic education could help to enhance China's ongoing industrial upgrade. The coefficient estimates on the pupil-teacher ratio are consistently around 0.7 and significant at the $1 \%$ level. This means for each 100 students to have one more fulltime teacher, the public education spending intensity would need to increase by $0.7 \%$. Alongside, the share of school-age population has a significant and negative effect on per student public education spending: for each $1 \%$ increase in this population share there is a $0.3 \%$ decrease in education spending intensity. Cities with more school children are inclined to spend less per student on education, a finding that is consistent with a quantity-quality tradeoff in education investment decision-making when the local government faces funding a rising number of school children (a rising youth dependency ratio). This result also reflects scale benefits in that fixed costs per student tend to fall as the number of students increases. The registered urban unemployment rate has an insignificant positive effect on education spending, which might by the fact that unemployed people require government support to fund their children's education. The share of the non-agriculture population has no significant effects, the reason behind which might relate to the fact that the urbanization rate lacks variation within an urban municipal district. The estimated effects of local public financial conditions are in line with our expectation and the reality in China. That is, municipal budgetary revenue and expenditure have a positive influence on education spending in that this is a leading source of funds for school operation expenses. The local fiscal self-sufficiency rate has an ambiguous effect on education spending.

Finally, we focus on the regression coefficient attached to the dummy variable "pilot pension reform". All the estimation results of the treatment effect of pilot pension reforms on public education spending are negative, as shown in columns (1)-(6). This suggests that reforms 
to fully funded individual accounts are associated with a reduction in the local government incentive to invest on public education. This result is broadly consistent with the theoretical prediction outlined in Section 2. It should be noted that the estimate on pilot reform is not statistically significant in model (1) and (2). As more control variables are included, however, the estimated effect becomes bigger across models (3)-(6). From column (3)-(6) we can see the coefficient estimates are -0.625 , at $10 \%$ level, -0.764 at $10 \%$ level, -0.781 at $10 \%$ level and 0.650 at $10 \%$ significance respectively. Based on the regression results, we can infer that pilot pension reforms are associated with reduced intensity of public education spending per student by an average 0.71 percent in the pilot provinces.

The empirical analysis in this subsection delivers a definitive quantitative result with respect to the effect of pilot pension reform on public education spending, and offers a conclusion that is consistent with our theoretical model. The underlying mechanism, however, still needs to be investigated. What more specifically is the reason for the decline in public education spending observed in pilot pension reform regions? Pension reform from a PAYG system to full-funded system usually involves huge transition costs, and in this case the reform also, inevitably, serves to diminish collective intergenerational dependence. These two consequences would both lead the government to spend less on education. Isolating the mechanism via which this effect works has important policy and inter-generational human capital implications. For example, a fall in the propensity to invest in public education arising from the costs of reform transition should be transitory or temporary, whereas a decrease due to erosion of dependence between generations should be long-term even permanent. The mechanism recognized in our theoretical outlay works exclusively through pension reform altering intergenerational dependence. We need to conduct further empirical analysis to examine which of the two channels - transition costs or altered intergenerational investment preferences - has the larger effect on the local government decision around education spending.

\subsection{The effect of central government subsidies for individual accounts}

In China's pilot fully-funded individual account reforms, the central government supported 8 provincial governments: three in northeastern China, alongside Shanxi, Henan, Hubei, Hunan and Xinjiang in piloting reform matching-funding of selected individual account subsidies. The central government's matching subsidy scheme is administrated by the National Council for Social Security Funding. The ultimate yield attached the scheme accrues however, to the owner of the individual account. In this subsection, we directly investigate and estimate the effect of extra gains on individual accounts generated by subsidies on local public education spending intensity.

Table 4 provides the estimated response of local government education spending to pilot pension reform with cities labeled in pilot reform provinces as unsubsidized or subsidized. Following equation (6), we divide the sample into three groups: a comparison group comprised 
of cities where the individual accounts are nominal and empty; the first type of treatment group, which comprises cities where the full funding of individual account pilot pension reforms is partially supported by central government; and the second type of treatment group which is comprised of cities in the pilot provinces that receive no related reform subsidies from central government. The estimated coefficients for our controls are almost entirely consistent with those of Table 3.

Table 4 Regression results for public education spending on pilot reform with subsidy

\begin{tabular}{|c|c|c|c|c|c|c|}
\hline \multicolumn{7}{|c|}{$\begin{array}{l}\text { Dependent variable: public education s } \\
\text { Non-pilot cities as comparison group }\end{array}$} \\
\hline & \multicolumn{6}{|c|}{ Model } \\
\hline & (1) & (2) & (3) & (4) & (5) & (6) \\
\hline $\begin{array}{l}\text { Pilot pension reform } \\
\text { with subsidies }\end{array}$ & $\begin{array}{l}-0.247 \\
(0.433)\end{array}$ & $\begin{array}{l}-0.281 \\
(0.438)\end{array}$ & $\begin{array}{l}-1.253 * \\
(0.505)\end{array}$ & $\begin{array}{l}-1.265 * \\
(0.527)\end{array}$ & $\begin{array}{l}-1.264 * \\
(0.532)\end{array}$ & $\begin{array}{l}-0.944 * \\
(0.510)\end{array}$ \\
\hline $\begin{array}{l}\text { Pilot pension reform } \\
\text { without subsidies }\end{array}$ & $\begin{array}{c}0.198 \\
(0.257)\end{array}$ & $\begin{array}{c}0.199 \\
(0.257)\end{array}$ & $\begin{array}{l}0.802 * * \\
(0.229)\end{array}$ & $\begin{array}{l}0.591 * \\
(0.285)\end{array}$ & $\begin{array}{c}0.552 \\
(0.315)\end{array}$ & $\begin{array}{r}0.165 \\
(0.325)\end{array}$ \\
\hline $\begin{array}{l}\text { Share of value added in } \\
\text { primary sector }(\%)\end{array}$ & $\begin{array}{c}0.085 \\
(0.059)\end{array}$ & $\begin{array}{c}0.087 \\
(0.059)\end{array}$ & $\begin{array}{c}0.061 \\
(0.047)\end{array}$ & $\begin{array}{c}0.058 \\
(0.055)\end{array}$ & $\begin{array}{c}0.058 \\
(0.055) \\
\end{array}$ & $\begin{array}{c}0.040 \\
(0.060)\end{array}$ \\
\hline $\begin{array}{l}\text { Share of value added in } \\
\text { tertiary sector. (\%) }\end{array}$ & $\begin{array}{l}0.048 * \\
(0.016)\end{array}$ & $\begin{array}{l}0.048 * \\
(0.016)\end{array}$ & $\begin{array}{c}0.026 \\
(0.016)\end{array}$ & $\begin{array}{c}0.026 \\
(0.016)\end{array}$ & $\begin{array}{c}0.026 \\
(0.016)\end{array}$ & $\begin{array}{l}0.016 \\
(0.019)\end{array}$ \\
\hline $\begin{array}{l}\text { Full-time teachers per } \\
100 \text { students in primary } \\
\text { and middle schools }\end{array}$ & $\begin{array}{l}0.763 * \\
(0.317) \\
\end{array}$ & $\begin{array}{l}0.768^{*} \\
(0.320) \\
\end{array}$ & $\begin{array}{l}0.634^{*} \\
(0.276) \\
\end{array}$ & $\begin{array}{l}0.638^{*} \\
(0.278)\end{array}$ & $\begin{array}{l}0.637^{*} \\
(0.278) \\
\end{array}$ & $\begin{array}{l}0.556^{*} \\
(0.260) \\
\end{array}$ \\
\hline $\begin{array}{l}\text { Share of school age } \\
\text { population }(\%)\end{array}$ & $\begin{array}{l}-0.259^{*} \\
(0.087)\end{array}$ & $\begin{array}{l}-0.259^{*} \\
(0.087)\end{array}$ & $\begin{array}{l}-0.282^{*} \\
(0.094)\end{array}$ & $\begin{array}{l}-0.281^{*} \\
(0.094)\end{array}$ & $\begin{array}{l}-0.282^{*} \\
(0.095)\end{array}$ & $\begin{array}{l}-0.341 * \\
(0.113)\end{array}$ \\
\hline $\begin{array}{l}\text { Registered urban } \\
\text { unemploy. rate, (\%) }\end{array}$ & & $\begin{array}{c}0.036 \\
(0.034) \\
\end{array}$ & $\begin{array}{r}0.029 \\
(0.024) \\
\end{array}$ & $\begin{array}{c}0.027 \\
(0.023) \\
\end{array}$ & $\begin{array}{c}0.027 \\
(0.023) \\
\end{array}$ & $\begin{array}{l}0.044 * \\
(0.024) \\
\end{array}$ \\
\hline $\begin{array}{l}\text { Local general bdgt } \\
\text { expenditure/GDP,(\%) }\end{array}$ & & & $\begin{array}{c}0.476^{* * * *} \\
(0.052)\end{array}$ & $\begin{array}{c}0.477 * * * \\
(0.052)\end{array}$ & $\begin{array}{c}0.477 * * * \\
(0.052)\end{array}$ & \\
\hline $\begin{array}{l}\text { Share of non- } \\
\text { agricultural population } \\
(\%)\end{array}$ & & & & $\begin{array}{l}-0.005 \\
(0.009) \\
\end{array}$ & $\begin{array}{l}-0.005 \\
(0.009) \\
\end{array}$ & $\begin{array}{r}0.004 \\
(0.009) \\
\end{array}$ \\
\hline $\begin{array}{l}\text { Local fiscal self- } \\
\text { sufficiency rate, }(\%)\end{array}$ & & & & & $\begin{array}{c}0.004 \\
(0.006) \\
\end{array}$ & $\begin{array}{c}-0.097 * * \\
(0.023) \\
\end{array}$ \\
\hline $\begin{array}{l}\text { Local general bdgt } \\
\text { revenue/GDP, (\%) }\end{array}$ & & & & & & $\begin{array}{l}1.037 * * \\
(0.272)\end{array}$ \\
\hline Observations & 3,203 & 3,202 & 3,202 & 3,161 & 3,160 & 3,160 \\
\hline City & 282 & 282 & 282 & 282 & 282 & 282 \\
\hline \multicolumn{7}{|c|}{ F test of equality, $\mathrm{H}_{0}: \beta$ (pilot with subsidy $)=\beta($ pilot without subsidy $)$} \\
\hline F statistics & 0.708 & 0.770 & 8.631 & 5.850 & 5.275 & 1.833 \\
\hline$p$-value & 0.418 & 0.399 & 0.0135 & 0.0341 & 0.0423 & 0.203 \\
\hline
\end{tabular}

Notes: Driscoll-Kraay standard errors clustered in brackets; all columns are estimated with a two-way fixed effects 
model.

* Significant at 10\%, ** Significant at 5\%, *** Significant at 1\%.

Review of the signs attached to the estimated coefficients relating to the pilot groups with subsidy and without subsidy reveals the regression results to support the negative effect of pilot pension reforms on public education spending under the different specifications, although the size and significance of the coefficients vary between the two pilot treatment groups. In columns (1)-(6), the marginal effects for the unsubsidized pilot group are insignificantly positive except for the results in columns (3) and (4), which are significant at 5\% and 10\% level respectively. These results show that for those regions where a fully accumulated system of individual accounts is piloted without central finance support, the pilot reforms have no demonstrable passive impact on local government education spending intensity.

There is also a significant and negative effect of pension reform on public education spending for subsidized pilot group in columns (3)-(6), with the size of the effects are similar to the results in Table 3. This finding implies that for pilot cities receiving central government subsidies, the pilot pension reform reduces the share of public education expenditure per student of GDP per capita by 0.94-1.26 percent. The estimations in columns (4)-(6) are credible since the endogeneity bias is addressed via important control variables that are progressively included. This is true in the case of the variables reflecting local financial conditions and social security expenditures, which are strongly correlated with pilot pension reforms. Thus, we can be confident in our conclusion that the passive effects on public education inputs of shifting to an individual pension account system observed in Table 3 mainly arise from change in the pilot regions that benefit from central finance pension reform subsidies.

In the aforementioned pilot cities, it is no longer permitted that funds contributed by employees and employers to individual accounts be re-directed to fund current PAYG system beneficiaries. As a result, the size of PAYG pension fund has inevitably fallen, and local governments face greater pressure in paying for current pensioners. In other words, the public budget constraint tightens due to transition of the pension system. This budget tightening might be a causal factor for the local government to reduce public education spending. However, the empirical results in Table 4 demonstrate in fact that pilot regions which had these transition costs subsidized by central government showed an ever-greater education spending effect than that shown in unsubsidized individual account reform regions. The reason for this cannot be explained by the decline in the disposable public budget. Moreover, subsidies from the central government to support the transition of pension reform slacken the long-term budget constraint of the selected provinces, which in principle provides an envelope that could lead local governments to spend more on education. But in fact, the higher extra earnings to individual accounts committed by the subsidies over the voluntary savings further weakens intergenerational ties, and thus exaggerates local governments' disincentives to invest in the 
productivity of future workers via current public education.

The regression results in Table 4 highlight the importance of the connection between generations, which should not be ignored in policy making. During the transition of China's pension reforms, the contribution rate to the social pooling account was reduced while the accumulation rate of personal accounts was increased. Both the privatisation of the pension system and also the higher extra gains to individual account committed by subsidies break the link between social security - pensions in retirement - and public education - the productivity of the next generation of workers - have a negative impact on local government educational inputs.

Estimates on the effects of pilot reform on education spending for subsidized group and unsubsidized group are moreover significantly different from each other - the p-value for an F test of equality is quite small for specifications (3)-(6) (Table 4). This supports the conclusions we have drawn above. The net effect for the unsubsidized group is almost negligible but for the subsidized group this is positive. The significant difference between the two groups implies that the income effect of the central subsidies to selected pilot areas is offset by the substitution effect. The subsidy for pension privatisation that is, enhances the incentive for the governments of pilot cities to save more and spend less on education, in turn leading to negative net effect. That is, the empirical evidence convincingly supports the theoretical assertion that pension privatisation, and its subsidization, induce an adverse passive influence on public education investment.

\subsection{Comparative analysis of public education spending and pension subsidies}

In this subsection, we focus on the government response in social security subsidies intensity to budget constraint change, and so we only investigate the effect of central government subsidies to funding personal account on social security subsidies and the endogeneity problem of pension reform can be put aside. That is, here we examine social security subsidies expenditure during the same sample period to examine whether the related empirical evidence supports our conclusion that the decrease in public education spending intensity following pension reforms cannot be simply attributed to reform transition costs or budget constraint change. We adopt social security subsidies expenditure and compare this with public education spending based on the following considerations. First, social security subsidies have a relatively complete statistical record across our sample years 1998-2009. Second, government expenditures on social security subsidies along with medical care and public education are in the broad category of general social welfare spending. To this extent, the two kinds of spending have some similarity from the perspective of budgetary expenditure. It is noted however, that data of social security subsidies is only available at prefecture level. This means that the variables we used in the following regression analysis are all measured at 
prefecture level, which has a larger statistical caliber than the data measured at the prefecture municipal district level used in Table 2 and 3.

Table 5 reports the DID estimation results for social security subsidies on pension reform estimated by two-way fixed effect model. The dependent variable in the regressions is the ratio of social security subsidies expenditure to GDP. Controls include the variables of local industry structure, urbanization rate, unemployment rate and financial conditions in Columns (1)-(5). The estimation results show opposite direction of effect of pension reform on social security subsidies to public education spending, and at the same time, the F test of equality strongly support significant difference between the coefficients for pilot cities with subsidies and without subsidies. In the unsubsidized pilot regions, funding individual accounts necessarily reduces the social funds available to local governments to pay for current pensioners. To ensure timely and full payment of the basic pension benefit, guarantee basic living standard of retirees, local governments usually tend to cut down the budgets for other items spending as a response to the real decrease in social pooling funds. As a result, in the pilot cities without subsidies, the social security subsidies intensity declines by 0.18 percent, while in the subsidized pilot cities, subsidies from the central government relaxes local government long-term budget and thus raises their social security subsidies expenditure by around 0.24 percent significantly. These findings obviously demonstrate the income effect generated by the subsidies for pension reform encourages more public spending.

We find that local governments respond to pilot pension reform in different ways with respect to public education expenditure and in the case where these reforms are subsidized by the central government. For social security subsidies, the response of local governments can be completely explained by change to the budget constraint that results from central government financial support; but for public education spending, we argue that the main reason for a subsidized local government to reduce investment in public education spending relates to the diminished bond between generations. That is, that privatisation of pensions weakens the link between pension entitlement and education input, an effect that is magnified by subsidies to the funding personal accounts.

Table 5 Regression Results for Social Security Subsidies on Pilot Reform and Subsidy

\begin{tabular}{|c|c|c|c|c|c|}
\hline \multicolumn{6}{|c|}{$\begin{array}{l}\text { Dependent variable: social security subs } \\
\text { Non-pilot cities as comparison group }\end{array}$} \\
\hline & \multicolumn{5}{|c|}{ Model } \\
\hline & (1) & (2) & (3) & (4) & (5) \\
\hline $\begin{array}{l}\text { Pilot pension reform } \\
\text { with subsidies }\end{array}$ & $\begin{array}{l}0.242 * \\
(0.129)\end{array}$ & $\begin{array}{l}0.234 * \\
(0.124)\end{array}$ & $\begin{array}{l}0.233 * \\
(0.126)\end{array}$ & $\begin{array}{l}0.233 * \\
(0.126)\end{array}$ & $\begin{array}{l}0.241 * \\
(0.132)\end{array}$ \\
\hline $\begin{array}{l}\text { Pilot pension reform } \\
\text { without subsidies }\end{array}$ & $\begin{array}{l}-0.179 * \\
(0.084)\end{array}$ & $\begin{array}{l}-0.196 * * \\
(0.084)\end{array}$ & $\begin{array}{l}-0.186 * \\
(0.085)\end{array}$ & $\begin{array}{l}-0.186 * \\
(0.085)\end{array}$ & $\begin{array}{l}-\mathbf{0 . 0 7 0} \\
(0.089)\end{array}$ \\
\hline
\end{tabular}




\begin{tabular}{|c|c|c|c|c|c|c|}
\hline \multicolumn{2}{|c|}{$\begin{array}{l}\text { Share of value added in } \\
\text { primary sector }(\%)\end{array}$} & $\begin{array}{l}-0.010^{*} \\
(0.005)\end{array}$ & $\begin{array}{l}-0.010^{*} \\
(0.005)\end{array}$ & $\begin{array}{l}-0.008 \\
(0.005)\end{array}$ & $\begin{array}{l}-0.008 \\
(0.005)\end{array}$ & $\begin{array}{l}-0.009 * \\
(0.005)\end{array}$ \\
\hline \multicolumn{2}{|c|}{$\begin{array}{l}\text { Share of value added in } \\
\text { tertiary sector }(\%)\end{array}$} & $\begin{array}{l}0.012 * * \\
(0.005)\end{array}$ & $\begin{array}{l}0.012 * \\
(0.005)\end{array}$ & $\begin{array}{l}0.011 * \\
(0.005)\end{array}$ & $\begin{array}{l}0.011^{*} \\
(0.005)\end{array}$ & $\begin{array}{l}0.011^{*} \\
(0.005)\end{array}$ \\
\hline \multicolumn{2}{|c|}{$\begin{array}{l}\text { Share of non-agricultural } \\
\text { population }(\%)\end{array}$} & $\begin{array}{l}0.000 \\
(0.001)\end{array}$ & $\begin{array}{l}-0.002 \\
(0.001)\end{array}$ & $\begin{array}{l}-0.002 \\
(0.001)\end{array}$ & $\begin{array}{l}-0.002 \\
(0.001)\end{array}$ & $\begin{array}{l}0.001 \\
(0.001)\end{array}$ \\
\hline \multicolumn{2}{|c|}{$\begin{array}{l}\text { Local general budgetary } \\
\text { revenue/GDP, }(\%)\end{array}$} & & $\begin{array}{l}0.014^{*} \\
(0.007)\end{array}$ & $\begin{array}{c}0.014 \\
(0.008)\end{array}$ & $\begin{array}{c}0.014 \\
(0.008)\end{array}$ & \\
\hline \multicolumn{2}{|c|}{$\begin{array}{l}\text { Local fiscal self- } \\
\text { sufficiency rate }(\%)\end{array}$} & & & & & $\begin{array}{c}-0.010^{* * *} \\
(0.002)\end{array}$ \\
\hline \multicolumn{2}{|c|}{$\begin{array}{l}\text { Registered urban } \\
\text { unemploy. rate }(\%)\end{array}$} & & & $\begin{array}{c}0.002 \\
(0.003)\end{array}$ & $\begin{array}{l}0.002 \\
(0.003)\end{array}$ & $\begin{array}{c}0.001 \\
(0.004)\end{array}$ \\
\hline \multicolumn{2}{|c|}{ Observations } & 3,660 & 3,660 & 3,541 & 3,541 & 3,541 \\
\hline \multicolumn{2}{|l|}{ City } & 331 & 331 & 324 & 324 & 324 \\
\hline \multicolumn{7}{|c|}{$\mathrm{F}$ test of equality, $\mathrm{H}_{0}: \beta$ (pilot with subsidy $)=\beta($ pilot without subsidy $)$} \\
\hline $\begin{array}{l}\mathrm{F} \\
\text { statistics }\end{array}$ & 8.640 & 8.614 & \multicolumn{2}{|c|}{8.582} & 8.582 & 6.623 \\
\hline$p$-value & 0.0135 & 0.0136 & \multicolumn{2}{|c|}{0.0137} & 0.0137 & 0.0259 \\
\hline
\end{tabular}

Notes: Driscoll-Kraay standard errors clustered in brackets; all columns are estimated with a two-way fixed effects model.

* Significant at 10\%, ** Significant at 5\%, *** Significant at 1\%.

\subsection{Robustness checks}

\subsubsection{Pre-treatment parallel trends test}

The DID methods in section 6.1 and 6.2 provide causal effect estimates if the treatment and control groups have followed a parallel trend in the absence of the pension reform. In this subsection, we check whether there were pre-existing differential trends in public education spending across pilot and non-pilot cities through use of a formal common trend test.

We estimate an expanded and dynamic version of model (19), in which we allow the postreform effects to vary with years since the pilot reform and for the existence of differential prereform trends:

$$
e d u_{i t}=\alpha+\beta \cdot y_{t}+\sum_{j=-5}^{5} \gamma_{j} \cdot\left(Y_{i t}^{j} \cdot P R_{i t}\right)+z_{i t}^{\prime} \delta+c_{i}+\varepsilon_{i t}
$$

where $Y_{i t}^{j}$ is a vector of indicators for the $j$ th year since provincial-level pilot reform implementation of fully funding individual accounts, with negative values of $j$ indicating prereform years. The pilot year for each specific reformed province is normalized to zero and changes are relative to that baseline year. The coefficients of primary interest in the dynamic 
model comprise the vector $\gamma_{j}$, the differential trends in public education spending between treatment and control groups surrounding pension reform. Table 6 reports the dynamic results for model (21), in which column (1)-(6) have the same specifications of controls as in Table (3). 
Table 6 Differential Time Trends Estimation

\begin{tabular}{|c|c|c|c|c|c|c|}
\hline \multicolumn{7}{|c|}{ Dependent variable: public education spending per student/GDP per capita (\%) } \\
\hline \multirow{2}{*}{$\gamma_{j}$} & \multicolumn{6}{|c|}{ Model } \\
\hline & (1) & $(2)$ & (3) & (4) & $(5)$ & $(6)$ \\
\hline \multirow{2}{*}{5 years before pilot } & -0.257 & -0.314 & -0.619 & -0.510 & -0.515 & -0.576 \\
\hline & $(1.145)$ & $(1.093)$ & $(0.745)$ & $(0.733)$ & $(0.734)$ & $(0.788)$ \\
\hline \multirow{2}{*}{4 years before pilot } & -0.158 & -0.202 & -0.256 & -0.161 & -0.155 & -0.423 \\
\hline & $(1.322)$ & (1.298) & $(0.826)$ & $(0.824)$ & $(0.824)$ & $(0.752)$ \\
\hline \multirow{2}{*}{3 years before pilot } & -1.085 & -1.121 & -0.826 & -0.741 & -0.737 & -0.772 \\
\hline & $(1.100)$ & $(1.070)$ & $(0.741)$ & $(0.732)$ & $(0.731)$ & $(0.781)$ \\
\hline \multirow{2}{*}{2 years before pilot } & -0.809 & -0.851 & -0.920 & -0.850 & -0.854 & -0.829 \\
\hline & $(1.027)$ & $(0.990)$ & $(0.691)$ & $(0.681)$ & $(0.682)$ & $(0.713)$ \\
\hline \multirow{2}{*}{1 years before pilot } & -0.207 & -0.238 & -0.688 & -0.606 & -0.604 & -0.461 \\
\hline & $(1.100)$ & $(1.072)$ & $(0.742)$ & $(0.732)$ & $(0.731)$ & $(0.760)$ \\
\hline \multirow{2}{*}{ Pilot year } & -0.864 & -0.913 & $-1.671^{*}$ & $-1.575^{*}$ & $-1.577 *$ & $-1.364 *$ \\
\hline & $(1.013)$ & $(0.967)$ & $(0.662)$ & $(0.651)$ & $(0.649)$ & $(0.646)$ \\
\hline \multirow{2}{*}{1 years after pilot } & 1.240 & 1.172 & -0.406 & -0.491 & -0.493 & 0.188 \\
\hline & $(1.776)$ & (1.707) & $(0.785)$ & $(0.775)$ & $(0.775)$ & $(1.024)$ \\
\hline \multirow{2}{*}{2 years after pilot } & 1.016 & 0.935 & 0.567 & 0.573 & 0.561 & 0.360 \\
\hline & (1.228) & (1.164) & $(0.883)$ & $(0.914)$ & $(0.919)$ & $(0.966)$ \\
\hline \multirow{2}{*}{3 years after pilot } & $-2.213^{*}$ & $-2.278 *$ & $-2.373 * *$ & $-2.272 * *$ & $-2.273 * *$ & $-2.279 *$ \\
\hline & $(1.170)$ & (1.114) & $(0.766)$ & $(0.765)$ & $(0.765)$ & $(0.842)$ \\
\hline \multirow{2}{*}{4 years after pilot } & $-5.520 * *$ & $-5.575^{* *}$ & $-6.485 * * *$ & $-6.448 * * *$ & $-6.448 * * *$ & $-5.953 * * *$ \\
\hline & $(1.738)$ & $(1.701)$ & $(1.652)$ & $(1.662)$ & $(1.665)$ & $(1.593)$ \\
\hline \multirow{2}{*}{5 years after pilot } & $-7.027 * * *$ & $-7.070 * * *$ & $-8.179 * * *$ & $-8.198 * * *$ & $-8.198 * * *$ & $-7.376 * * *$ \\
\hline & $(2.014)$ & (1.994) & (2.077) & $(2.080)$ & $(2.085)$ & $(2.032)$ \\
\hline Observations & 3,203 & 3,202 & 3,202 & 3,161 & 3,160 & 3,160 \\
\hline R-squared & 0.186 & 0.186 & 0.506 & 0.506 & 0.506 & 0.430 \\
\hline Number of city & 282 & 282 & 282 & 282 & 282 & 282 \\
\hline
\end{tabular}

Notes: Driscoll-Kraay standard errors clustered in brackets; all columns are estimated with a two-way fixed effects model.

* Significant at 10\%,** Significant at 5\%,*** Significant at $1 \%$.

By estimating changes in relative outcomes preceding pension reform the dynamic framework can be used to test the validity of the DID framework. From Table 6, we find statistically indistinguishable pre-treatment trends for pilot and non-pilot cities but significant and growing relative disincentive to spending on public education for pilot cities after pension reform. This finding is robust to alternative covariates specifications. The lack of unparallel trends provides support for assigning a causal inference for the negative impact of privatization of pension account on investment on public education which we make in section 6.1 and 6.2. 


\subsubsection{Matched difference-in-difference estimators}

Another concern with our DID models is that pilot and non-pilot cities may differ in ways that are related to their trends over time and even in ways related to the central government's pilot selection decision list, which potentially induces an endogeneity problem. Table 2 of descriptive statistics displays significant differences between the reformed and non-reformed cities in terms of observables. This suggests that unobservables could differ as well. For example, a more conservative attitude of municipal government toward public spending in general could drive both pension reform and reduced education spending. DID estimate could difference out such permanent or constant confounders while transitory shocks which cannot be controlled for might also bias our causal inference.

In this section, we employ the Matched Difference-in-Difference method, which combines the strengths of DID and Matching, to address this potential confounding issue. Especially, through matching, this method can control for observed pre-treatment characteristics that possibly create non-parallel selection bias between treated and controls (Encina, 2013; Abadie, 2005; Smith and Todd, 2005; Heckman et al., 1997). We estimate the average treatment effect of pension reform on public education spending in two steps.

In the first stage, we perform a kernel propensity score estimation based on each city's pre-treatment characteristics including GDP per capita, share of school age population, proportion of local general budgetary revenue over GDP and share of value-added in the tertiary sector. These variables are thought to be closely related to central government selection on pilot provinces. Moreover, given these observables, we assume that the unobservables follow the same distribution of dynamics for pilot and non-pilot cities. We estimate a Probit regression using pilot as treatment variable and derive the weight for each non-reformed city from kernel density function and propensity score. In our sample, we have 10 provinces that carried out pension reform, but at different points in time, therefore, we estimate the propensity score and the weight for each sample of one pilot province together with all non-pilot provinces respectively.

In the second stage, we run a weighted DID regression for each pilot province, which is specified as Equation (22). $w_{i t}$ is the weight derived for each control city based on its propensity score; and the other variables in the regression are defined as the same as in Equation (19). According to kernel propensity score matching, the unreformed city is weighted more heavily if it is closer to the reformed city by propensity score. The matched DID estimators for each pilot province is delivered by:

$$
w_{i t} \cdot e d u_{i t}=\alpha \cdot w_{i t}+\beta \cdot\left(w_{i t} \cdot y_{t}\right)+\gamma \cdot\left(w_{i t} \cdot P R_{i t}\right)+\left(w_{i t} \cdot z_{i t}\right)^{\prime} \delta+w_{i t} \cdot c_{i}+w_{i t} \cdot \varepsilon_{i t}
$$

Then we aggregate the effects estimated by matched DID over 10 reformed provinces under 6 specifications of different covariates as in Table 3. The overall effects of pilot pension reform and the effects of subsidy from central government on public education spending are 
displayed in Table 7. We also conduct checks for balance between treatment and control groups based on individual t-tests for each pre-treatment covariate used to estimate the propensity score and for each pilot province sample. These test results are also reported in Table 7. 
Table 7 Matched difference-in-difference estimation and balancing test

\begin{tabular}{|c|c|c|c|c|c|c|c|}
\hline & \multicolumn{7}{|c|}{ Model } \\
\hline & (1) & (2) & (3) & (4) & \multicolumn{2}{|c|}{$(5)$} & (6) \\
\hline $\begin{array}{l}\text { Avg. treatment effect of } \\
\text { pilot reform }^{a}\end{array}$ & $\begin{array}{l}-0.327 * \\
(0.208)\end{array}$ & $\begin{array}{c}-0.424 * * \\
(0.200)\end{array}$ & $\begin{array}{c}-0.888 * * * \\
(0.160)\end{array}$ & $\begin{array}{c}-1.015 * * * \\
(0.161)\end{array}$ & \multicolumn{2}{|c|}{$\begin{array}{c}-0.924 * * * \\
(0.159)\end{array}$} & $\begin{array}{l}-0.616 * * \\
(0.166)\end{array}$ \\
\hline p-value & 0.075 & 0.031 & 0.000 & 0.000 & \multicolumn{2}{|c|}{0.000} & 0.002 \\
\hline $\begin{array}{l}\text { Avg. treatment effect of } \\
\text { pilot reform with subsidy }\end{array}$ & $\begin{array}{l}-0.523 * * \\
(0.258)\end{array}$ & $\begin{array}{c}-0.665 * * \\
(0.241)\end{array}$ & $\begin{array}{c}-1.480 * * * \\
(0.186)\end{array}$ & $\begin{array}{c}-1.663 * * * \\
(0.182)\end{array}$ & \multicolumn{2}{|c|}{$\begin{array}{c}-1.532 * * * \\
(0.185) \\
\end{array}$} & $\begin{array}{c}-1.003 * * * \\
(0.190)\end{array}$ \\
\hline p-value & 0.045 & 0.017 & 0.000 & 0.000 & \multicolumn{2}{|c|}{0.000} & 0.001 \\
\hline $\begin{array}{l}\text { Avg. treatment effect of } \\
\text { pilot reform without } \\
\text { subsidy }\end{array}$ & $\begin{array}{c}0.130 \\
(0.340)\end{array}$ & $\begin{array}{c}0.137 \\
(0.354)\end{array}$ & $\begin{array}{c}0.493 \\
(0.314)\end{array}$ & $\begin{array}{c}0.495 \\
(0.330)\end{array}$ & \multicolumn{2}{|c|}{$\begin{array}{c}0.494 \\
(0.307)\end{array}$} & $\begin{array}{c}0.288 \\
(0.330)\end{array}$ \\
\hline p-value & 0.369 & 0.368 & 0.128 & 0.136 & \multicolumn{2}{|c|}{0.125} & 0.237 \\
\hline \multicolumn{8}{|c|}{ Balancing test of difference in means of pre-treatment covariates } \\
\hline \multirow{2}{*}{ Weighted mean of covariates ${ }^{\mathrm{d}}$} & \multirow{2}{*}{$\begin{array}{l}\text { Non-pilot } \\
\text { group }\end{array}$} & \multirow{2}{*}{$\begin{array}{l}\text { Pilot } \\
\text { group }\end{array}$} & \multirow{2}{*}{ Diff. } & \multicolumn{4}{|c|}{$\mathrm{H}_{0}: \mathrm{E}(\mathrm{diff})=0$ for each 10 pilot prov } \\
\hline & & & & \multicolumn{2}{|c|}{$\#$ rejected at $5 \%$} & \multicolumn{2}{|c|}{$\#$ rejected at $1 \%$} \\
\hline GDP per capita, RMB & 14181.818 & 15181.818 & 755.508 & \multicolumn{2}{|l|}{3} & & 2 \\
\hline Share of school age pop. (\%) & 13.396 & 13.344 & -0.052 & \multicolumn{2}{|l|}{3} & & 3 \\
\hline $\begin{array}{l}\text { Local general bdgt } \\
\text { revenue/GDP (\%) }\end{array}$ & 5.424 & 5.413 & -0.011 & \multicolumn{2}{|l|}{3} & & 1 \\
\hline $\begin{array}{l}\text { Share of value added in } \\
\text { tertiary sector }(\%)\end{array}$ & 37.221 & 37.283 & 0.061 & \multicolumn{2}{|l|}{2} & & 0 \\
\hline
\end{tabular}

Note:

${ }^{\text {a }}$ The average treatment effect over matched DID estimation for the 10 pension reform pilot provinces.

${ }^{\mathrm{b}}$ The average treatment effect over matched DID estimation for 7 pilot provinces subsidized by central government (Liaoning, Heilongjiang, Jilin, Shanxi, Henan, Hubei and Hunan).

c The average treatment effect over matched DID estimation for 3 pilot provinces without subsidy from central government (Shandong, Zhejiang and Jiangsu).

$\mathrm{d}$ The weighted mean of covariates for non-pilot group are calculated by using kernel weight.

Standard errors clustered in brackets.

* Significant at $10 \%, * *$ Significant at $5 \%, * * *$ Significant at $1 \%$.

Very few of the 40 balancing tests are rejected at $5 \%$ or $1 \%$ significance level, implying that cities with the same propensity score generally have the same distribution of observable covariates independent of treatment status, and thus that the method of matching is justified. By matched DID we get very similar estimated effects of pilot pension reform on public education spending intensity to the results in Tables 3 and 4. That is, compared to cities that have not experimented with reform, the municipality negatively responds to pilot reform of funding individual accounts by decreasing government education spending intensity. And again, the negative responses exclusively emerge in those pilot provinces whose reforms are partly supported by central government subsidies, while pension reform seems to have had little impact on the public education spending decisions of unsubsidized municipalities. The size of the treatment effect for pilot cities receiving central government subsidies offered by matched 
DID is 1-1.6 percent, quite close to $0.94-1.26$ percent of Table 4.

\section{Conclusion}

The present era is one of unprecedented population aging across most developed and also many middle-income countries. Redistribution of resources between generations is accordingly an increasingly important and contentious issue, and should now be attracting more attention in the literature. There remains however, relatively little in the literature that elaborates the direct or indirect impacts of population aging on economies.

Here we have studied the impact of reforms to the pension system on education expenditure. We developed a three-period OLG model, in which the working generation invests in the education of the next generation as part of a contract that provides for higher pension dividends in old age. Economic theory suggests that improving the share of pensions that are linked directly to each individual's own working years contributions instead of a pooled account may reduce the marginal individual return of education investment. This in turn links pension privatisation negatively with public education spending. Recent variation in pension reforms between provinces in China provides conditions of a natural experiment that enable empirical exploration of this relationship.

We specifically used a DID framework to test prefecture-level district panel data covering years 1998-2009. The results agree with our theoretical outlay, and offer specific quantitative effects estimation. Adopting the ratio of public education expenditure per student to GDP per capita as the benchmark indicator, each unit of pension reforms in the direction of privatisation is associated with a decrease in the intensity of education expenditure by some 0.7 percent. In cases were a central government subsidy was used to incentive private savings, the intergenerational link was further weakened, and this was associated with a greater fall again in public education expenditures. Selective privatisation of pensions that is, appears to have negative intergenerational spillover effects.

The relationship between pensions and public education expenditures empirically studied herein in the case of China is important within the policy debate on population aging. Amid any package of pension reforms, economic assessments should include evaluation of the impact on education within the set of transition costs - short and long run. China's pension reforms that relatively enriched individual accounts are associated with negative impacts on public education spending, even though the proportion of individual accounts remained relatively low.

On the other hand, central government pension subsidies granted to the old industrial bases in China's northeast and the less developed areas of China's central eastern region have improved the return rates of individual accounts. This marks a positive turning point in 
sustainable pension management in China. Understanding how to balance this with an apparent resulting fall in the propensity of today's working-age population to invest in the human capital of tomorrow's working generation is a challenge for policy makers to better understand and resolve.

Populations around the world are aging increasingly rapidly, putting pressure on the pension sustainability and increasing intergenerational frictions. And yet, even in fiscally centralised countries like China, pension reforms are hotly politically contested and thus difficult to adjust toward long-run optimal intergenerational outcomes. They also have many, often unintended, consequences. Our study, suggests that in studying pension sustainability and fairness alternatives, policy makers should also calibrate the impact of prospective pension changes on the public investment in education. If pension changes undermine long-run equitable human capital accumulation this itself will reduce future economic growth, and in turn will merely serve to magnify future pressure on pension sustainability.

Amid unprecedented population aging across the Americas, East Asia and Europe it is imperative that researchers shed greater light on the long-run implications of different aged care and welfare systems. This is one means of supporting constructive and open political debate that in turn may better support policy-makers to implement evidence-backed policy reforms. 


\section{Appendix A}

The local government's optimization problem is:

$$
\begin{gathered}
\operatorname{Max} \quad G=\ln c_{2, t}+\rho \ln c_{3, t+1} \\
\text { s.t. } c_{2, t}=\frac{1}{1+\rho}\left[\left(1-\lambda_{t}^{p}-\lambda_{t}^{m}-\tau_{t}\right) w_{t} h_{t}+\frac{1}{1+r_{t+1}}\left(p_{t+1}+m_{t+1}\right)\right] \\
c_{3, t}=\left(1+r_{t+1}\right) \rho c_{2, t} \\
m_{t+1}+p_{t+1}=\lambda_{t+1}^{p} w_{t+1}\left(e_{t} w_{t}\right)^{\beta} h_{t}+\theta \lambda_{t}^{m} w_{t} h_{t}\left(1+r_{t+1}\right) \\
e_{t} w_{t} h_{t}=\tau_{t} w_{t} h_{t}
\end{gathered}
$$

Substituting (A.2)-(A.5) into (A.1) gives:

$$
G=(1+\rho) \ln \left[\frac{w_{t} h_{t}}{1+\rho}\left(1-\lambda_{t}^{p}-\lambda_{t}^{m}-e_{t}+\frac{\lambda_{t+1}^{p} w_{t+1} e_{t}^{\beta} w_{t}^{\beta-1}}{1+r_{t+1}}+\theta \lambda_{t}^{m}\right)\right]+\rho \ln \left[\left(1+r_{t+1}\right) \rho\right]
$$

Since a local government sees the wage rate and interest rate in the next period as given, the government just choose the optimal public education spending. So the FOC satisfies:

$$
\frac{d G}{d e_{t}}=\frac{\left(-w_{t} h_{t}+\frac{\lambda_{t+1}^{p} w_{t+1} \beta e_{t}^{\beta-1} w_{t}^{\beta} h_{t}}{1+r_{t+1}}\right.}{\left[\frac{w_{t} h_{t}}{1+\rho}\left(1-\lambda_{t}^{p}-\lambda_{t}^{m}-e_{t}+\frac{\lambda_{t+1}^{p} w_{t+1} e_{t}^{\beta} w_{t}^{\beta-1}}{1+r_{t+1}}+\theta \lambda_{t}^{m}\right]\right.}=0
$$

From equation (A.6), we can get:

$$
e_{t}^{1-\beta}=\frac{w_{t+1}}{1+r_{t+1}} \beta \lambda_{t+1}^{p} w_{t}^{\beta-1}
$$




\section{References}

1. Abadie, A., 2005. Semiparametric Difference-in-Differences Estimators. Review of Economic Studies 72(1), 1-19.

2. Acemoglu, D., 2009. Introduction to Modern Economic Growth. Princeton University Press, Princeton.

3. Arvate, P. R., and A. C. Zoghbi (2010). Intergenerational Conflict and Public Education Expenditure When There is Co-residence between the Elderly and Young. Economics of Education Review, 29(6), 1165-1175.

4. Becker, G. S. and R. J. Barro, 1988. A Reformulation of the Economic Theory of Fertility. The Quarterly Journal of Economics 103(1), 1-25.

5. Bloom, D.E., D. Canning and G. Fink, 2010. Implications of Population Ageing for Economic Growth. Oxford Review of Economic Policy 26 (4), 583-612.

6. Boldrin, M. and A. Montes, 2005. The Intergenerational State Education and Pensions. Review of Economic Studies 72(3), 651-664.

7. Boldrin, M. and A. Montes, 2009. Assessing the Efficiency of Public Education and Pensions. Journal of Population Economics 22(2), 285-309.

8. Brunner, E., and E. Balsdon (2004). Intergenerational Conflict and the Political Economy of School Spending. Journal of Urban Economics, 56, 369-388.

9. Brunner, J. K., 1993. Transition from a Pay-as-you-go to a fully Funded Pension System: the Case of Differing Individuals and Intergenerational Fairness. Journal of Public Economics 60 (1), 131-146.

10. Buiter, W. H. and K. M. Kletzer, 1995. Capital Mobility, Fiscal Policy and Growth under Self-financing of Human Capital Formation. NBER Working paper No.5120.

11. Chen, T. and J. A. Turner, 2014. Social Security Individual Accounts in China: Toward Sustainability in Individual Account Financing. Sustainability 6(8), 5049-5064.

12. Choi, Y. J. (2006). Transformations in economic security during old age in Korea: The implications for public-pension reform. Ageing \& Society, 26(4), 549-565.

13. Cigno, A. and M. Werding (2007), Children and Pensions, Cambridge, Massachusetts: MIT Press

14. Cigno, A., 2010. How to Avoid a Pension Crisis: A Question of Intelligent System Design. CESifo Economic Studies 56(1): 21-37.

15. Cigno, A., A. Luporini and A. Pettini, 2003. Transfers to Families with Children as a Principal-Agent Problem. Journal of Public Economics 87(5), 1165-1172.

16. Donald, S. G. and K. Lang, 2007. Inference with Difference-in-Differences and Other Panel Data. The Review of Economics and Statistics 89(2), 221-233.

17. Encina, J. (2013). Pension reform in Chile: A difference in difference matching estimation. Estudios de economía, 40(1).

18. Gradstein, M. and M. Kaganovich, 2004. Aging Population and Education Finance. Journal of Public Economics, 88(12): 2469-2485. 
19. Harris, A. R., W. N. Evans and R. M. Schwab, 2001. Education Spending in an Aging America. Journal of Public Economics 81 (3), 449-472.

20. Heckman, J., H. Ichimura, and P. Todd (1997). Matching as an Econometric Evaluation Estimator: Evidence from Evaluating a Job Training Program. Review of Economic Studies 64, 605-654.

21. Hoechle, D., 2007. Robust Standard Errors for Panel Regressions with Cross-Sectional Dependence. The Stata Journal 7(3), 281-312.

22. Iturbe-Ormaetxe, I. and G. Valera, 2004. Social Security Reform and the Support for Public Education. Journal of Population Economics 25(2), 609-634.

23. Johnston, L., X. Liu, M. Yang and X. Zhang, 2016. Getting Rich after Getting Old: China's Demographic and Economic Transition in Dynamic International Context. China's New Sources of Economic Growth 1, 215.

24. Kaganovich M. and Meier V., 2012. Social Security Systems, Human Capital, and Growth in a Small Open Economy. Journal of Public Economic Theory, 14(4):573-600.

25. Kaganovich, M. and I. Zilcha, 1999. Education, Social Security, and Growth. Journal of Public Economics 71(2), 289-309.

26. Kaganovich, M. and I. Zilcha, 2012. Pay-as-you-go or Funded Social Security? A General Equilibrium Comparison. Journal of Economic Dynamics \& Control 36(4), 455-467.

27. Kemnitz, A., 2000. Social Security, Public Education, and Growth in a Representative Democracy. Journal of Population Economics, 13(2): 443-462.

28. Kurban, H., R. M. Gallagher and J. J. Persky, 2015. Demographic Changes and Education Expenditures: A Reinterpretation. Economics of Education Review 45, 103-108.

29. Mason, A., R. Lee and J. X. Jiang, 2016. Demographic Dividends, Human Capital, and Saving. The Journal of the Economics of Ageing 7, 106-122.

30. Mu, R., \& Du, Y. (2015). Pension coverage for parents and educational investment in children: Evidence from urban China. The World Bank Economic Review, lhv060.

31. Ohtake, F., and S. Sano (2010). The Effects of Demographic Change on Public Education in Japan. The Economic Consequences of Demographic Change in East Asia, NBER-EASE 19, 193-223.Takatoshi Ito and Andrew Rose, editors.

32. Orszag, P. R., \& Stiglitz, J. E. (2001). Rethinking pension reform: Ten myths about social security systems. New ideas about old age security, 17-56.

33. Pogue, T. F. and L. G. Sgontz, 1977. Social Security and Investment in Human Capital. National Tax Journal 30(2), 157-169.

34. Poterba J. M., 1998. Demographic Change Intergenerational Linkages and Public Education. American Economic Review 88(2): 315-320.

35. Poterba, J. M., 1997. Demographic Structure and the Political Economy of Public Education. Journal of Policy Analysis \& Management 16(1): 48-66.

36. Rangel, A., 2003. Forward and Backward Intergenerational Goods: Why is Social Security Good for the Environment? The American Economic Review 93(3), 813-834.

37. Sinn, H.-W. 2004. The Pay-As-You-Go Pension System as Fertility Insurance and an 
Enforcement Device. Journal of Public Economics 88(7-8): 1335-1357.

38. Smith, J. and P. Todd (2005). Does Matching Overcome Lalonde's Critique of Nonexperimental Estimators? Journal of Econometrics, 125 (1-2), 305-353.

39. Tokuoka, K. (2012). Intergenerational Implications of Fiscal Consolidation in Japan, IMF Working Paper No. 12/197 (August).

40. World Bank, 1996. China: Pension System Reform.

41. Yuan, C. and L. Zhang (2015). Public Education Spending and Private Substitution in Urban China, Journal of Development Economics 115, 124-139.

42. Zhu, Y., 2002. Recent Developments in China's Social Security Reforms. International Social Security Review 55(4), 39-54. 